Article

\title{
Rare Earth Elements in Planetary Crusts: Insights from Chemically Evolved Igneous Suites on Earth and the Moon
}

\author{
Claire L. McLeod ${ }^{1, *}$ and Barry J. Shaulis ${ }^{2}$ \\ 1 Department of Geology and Environmental Earth Sciences, 203 Shideler Hall, Miami University, \\ Oxford, OH 45056, USA \\ 2 Department of Geosciences, Trace Element and Radiogenic Isotope Lab (TRaIL), University of Arkansas, \\ Fayetteville, AR 72701, USA; Bshaulis@uark.edu \\ * Correspondence: mcleodcl@miamioh.edu; Tel.: +1-513-529-9662
}

Received: 5 July 2018; Accepted: 8 October 2018; Published: 16 October 2018

\begin{abstract}
The abundance of the rare earth elements (REEs) in Earth's crust has become the intense focus of study in recent years due to the increasing societal demand for REEs, their increasing utilization in modern-day technology, and the geopolitics associated with their global distribution. Within the context of chemically evolved igneous suites, 122 REE deposits have been identified as being associated with intrusive dike, granitic pegmatites, carbonatites, and alkaline igneous rocks, including A-type granites and undersaturated rocks. These REE resource minerals are not unlimited and with a $5-10 \%$ growth in global demand for REEs per annum, consideration of other potential REE sources and their geological and chemical associations is warranted. The Earth's moon is a planetary object that underwent silicate-metal differentiation early during its history. Following $~ 99 \%$ solidification of a primordial lunar magma ocean, residual liquids were enriched in potassium, REE, and phosphorus (KREEP). While this reservoir has not been directly sampled, its chemical signature has been identified in several lunar lithologies and the Procellarum KREEP Terrane (PKT) on the lunar nearside has an estimated volume of KREEP-rich lithologies at depth of $2.2 \times 10^{8} \mathrm{~km}^{3}$. This reservoir therefore offers a prospective location for future lunar REE exploration. Within the context of chemically evolved lithologies, lunar granites are rare with only 22 samples currently classified as granitic. However, these extraterrestrial granites exhibit chemical affinities to terrestrial A-type granites. On Earth, these anorogenic magmatic systems are hosts to U-Th-REE-ore deposits and while to date only U-Th regions of enrichment on the lunar surface have been identified, future exploration of the lunar surface and interior may yet reveal U-Th-REE regions associated with the distribution of these chemically distinct, evolved lithologies.
\end{abstract}

Keywords: rare earth elements; igneous; granite; Moon; lunar; resources

\section{Introduction}

Ore deposits associated with chemically evolved igneous rock suites have been the intense focus of research over the past several decades [1-14]. Magmatic-associated mineral deposits are mineralogically and chemically diverse, occur in a range of geological settings, and have long been the target of the mineral industry. They host a wide array of precious and semi-precious metals including tin $(\mathrm{Sn})$, tungsten $(\mathrm{W})$, lithium $(\mathrm{Li})$, molybdenum $(\mathrm{Mo})$, bismuth $(\mathrm{Bi})$, iron $(\mathrm{Fe})$, copper $(\mathrm{Cu})$, and silver $(\mathrm{Ag})$, and the rare earth elements (REEs) which includes the lanthanide series (Lanthanum (La) to lutetium $(\mathrm{Lu})$ in addition to scandium $(\mathrm{Sc})$ and yttrium $(\mathrm{Y})$ ).

The occurrence, distribution, and potential for economic extraction of the REEs have become the intense focus of world markets in recent years $[15,16]$. This has been due to the extensive use 
of these elements in modern day technology, their criticality in supporting research throughout medicine, military-based technologies, and communication, and their role in the development of clean energy technologies [17-20]. These elements do not occur naturally as metals like copper (Cu) or lead $(\mathrm{Pb})$, instead being complexed in a wide array of different mineral types from carbonates to silicates to phosphates. According to the United States Geological Survey (USGS) [21], there are currently 799 major REE mineral-bearing deposits identified globally, of which 122 are associated with alkaline igneous activity (not including carbonatites, of which there are 149 [22]). These deposits are often specifically associated with chemically evolved, intrusive dike, granitic pegmatite, and/or alkaline igneous complexes, and are the primary focus of this review.

The mineralogy of Earth's crust is dominated by common rock-forming silicate minerals, e.g., quartz, feldspars, ferromagnesium minerals, amphiboles, and micas. The elemental budget of Earth's crust is therefore characterized by the cations which are integral structural components to these phases (Figure 1). Combined, the major rock-forming minerals account for 99\% of Earth's upper crustal element budget with only $2.16 \%$ of the remaining $1 \%$ being comprised of the REEs (Figure 1 ).

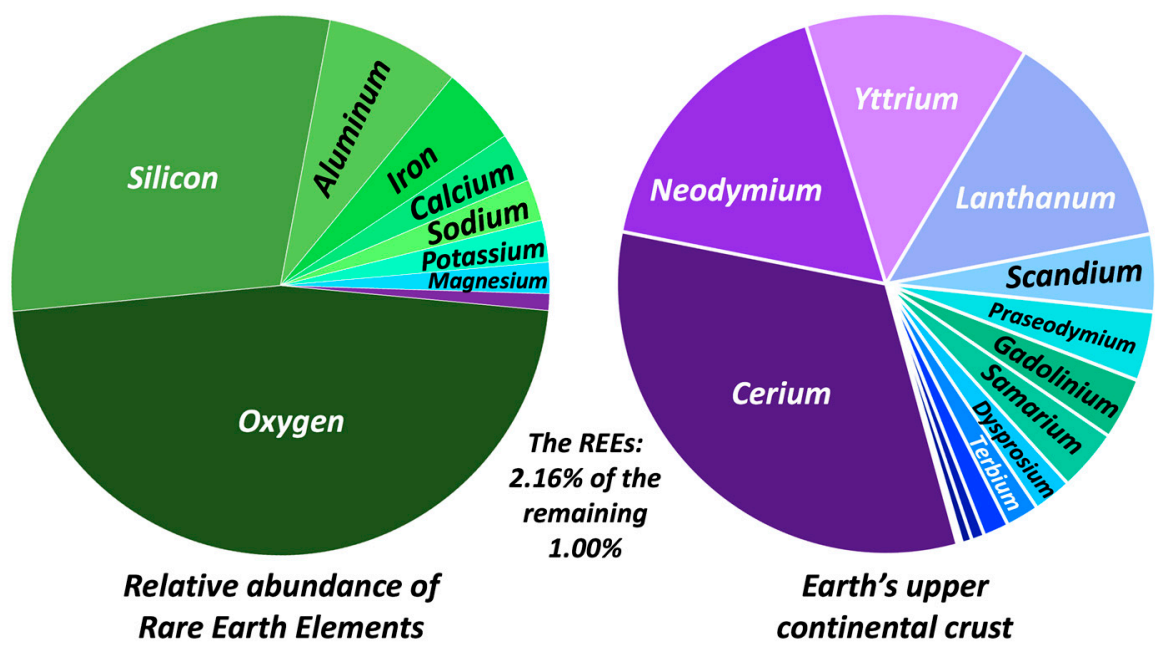

Figure 1. Summary of Earth's upper crustal element budget [23]. Silicon and O account for 76\%, with $\mathrm{Al}$ at $8 \%$, total alkalis $(\mathrm{Na}, \mathrm{Ca}, \mathrm{K})$ at $\sim 8 \%$, and $\mathrm{Fe}$ and $\mathrm{Mg}$ contributing $6.5 \%$ combined. From the remaining $1 \%$ (these elements are often referred to as trace elements), the REEs contribute $2.16 \%$ with $\mathrm{Ce}, \mathrm{Nd}, \mathrm{Y}$, and La the most abundant at $32 \%, 17 \%$, and $13 \%$ (Y and La) respectively of the total REE budget. $\mathrm{Yb}, \mathrm{Ho}, \mathrm{Eu}, \mathrm{Er}, \mathrm{Tm}$, and Lu collectively comprise 3.2\% of the REE budget (not shown above).

Despite comprising $<0.022 \%$ of the elemental budget of Earth's upper crust (Figure 1), the REEs are one of modern-day societies most critical commodities. They are fundamental to today's world economy and with a global shift towards establishing clean and green energy sources, the demand for REEs will only continue to increase [16,20].

It is therefore the objective of this paper to (1) consider and evaluate the occurrence of Earth's REE resources associated with chemically evolved igneous alkaline suites; (2) compare and contrast these with the association of REE-mineral bearing granitic lithologies on another planetary body which underwent metal-silicate differentiation, the Earth's moon; and (3) evaluate the potential for economically justifiable extraction of lunar REEs. With our increasing reliance on natural resources, and the need for REEs to sustain the research and development of future technologies, the exploitation of space-based resources is an inevitable reality of humanities future mineral exploration $[19,24]$.

\section{Geological and Mineralogical Occurrences}

The REE deposits associated with evolved magmatic systems share a suite of common characteristics [25]:

(1) Predominantly associated with alkaline environments; 
(2) Exhibit complementary High Field Strength Element (HFSE) enrichment;

(3) Contain phosphate and/or fluoride REE-bearing ore minerals (see Table 1);

(4) REE enrichment is associated with magmatic crystallization processes (see Section 3);

(5) Enhancement of REE deposits has been promoted through redistribution of REEs by hydrothermal agents;

(6) Fenitization (metasomatism of the surrounding country rock by alkali-dominated fluids).

Volumetrically, alkaline rocks represent $<1 \%$ of all igneous rocks types yet half of the nomenclature associated with igneous lithologies refers to alkaline systems [26] with no less than 400 alkaline rock varieties [27]. The generation of these magmas has garnered the attention of mineralogists, petrologists, and geochemists for decades for reasons beyond academic interest due to their resulting mineralogical diversity and the presence of valuable resources as introduced above (including niobium and tantalum, in addition to the REEs).

For the purposes of this contribution, only alkali-granite-syenite systems and their associated REE reserves and potentials are discussed further. This is because out of the environments in which REEs have been identified on Earth (e.g., carbonatites, placer-deposits), only granites have been identified on another planetary body.

Figure 2a,b summarizes (based on data available from the USGS) the worldwide occurrence of REE deposits associated with alkaline igneous rocks that are currently being exploited, in addition to potential future resources.

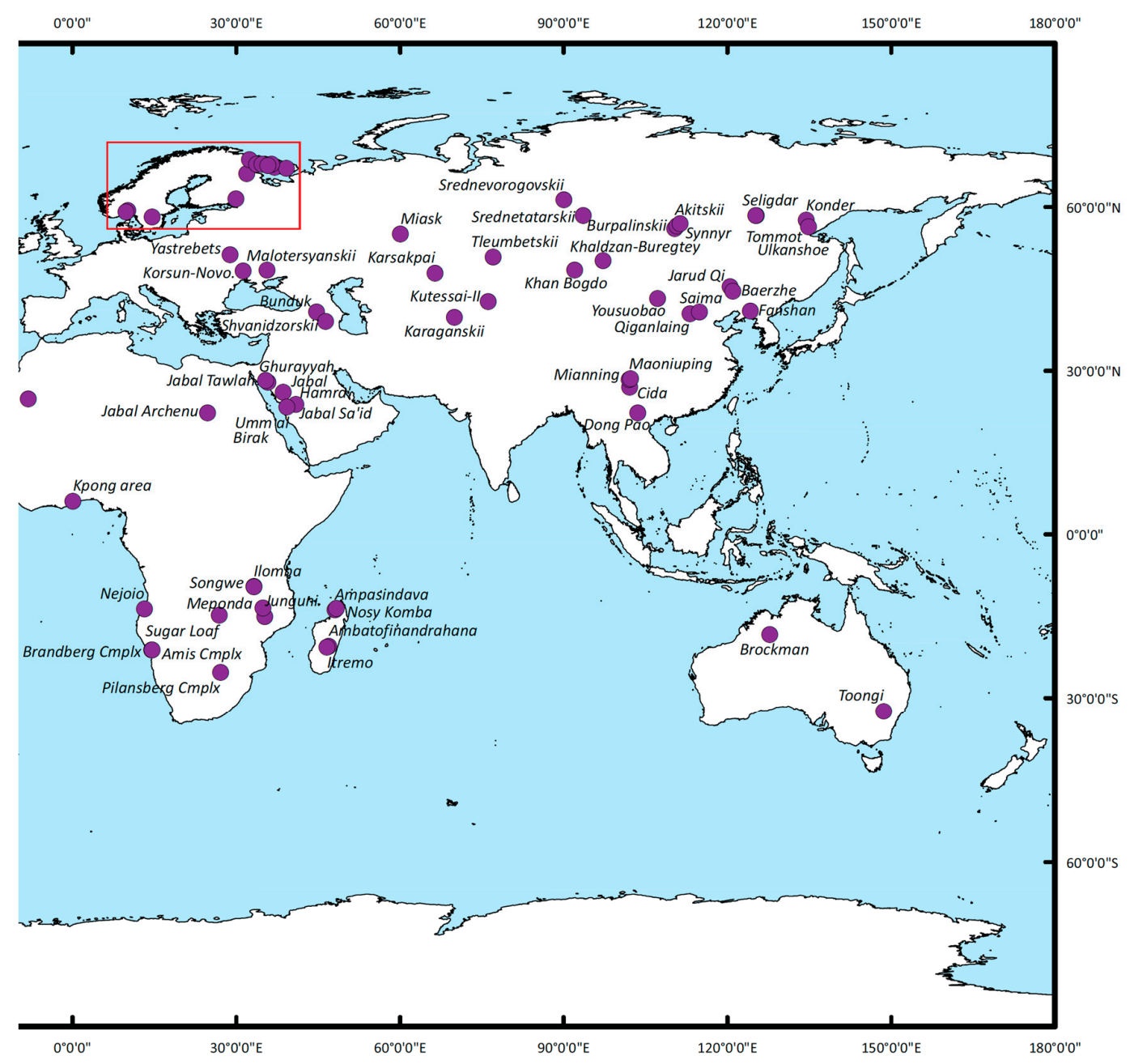

(a)

Figure 2. Cont. 


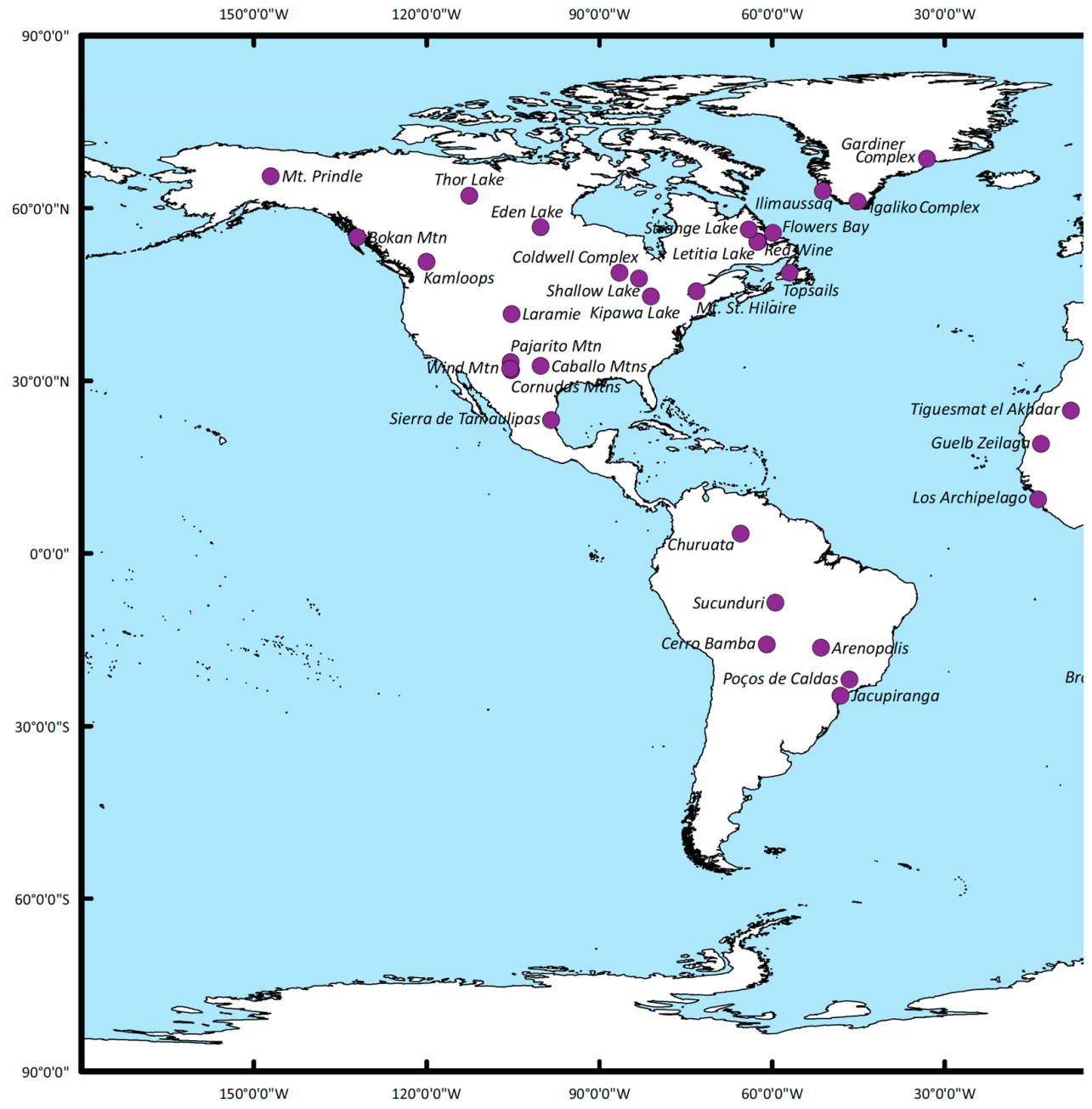

(b)

Figure 2. (a) Summary of the global distribution of major REE resources associated with alkali igneous deposits ( $n=100$, for 22 deposits no specific REE mineralogy is reported) [11,28] for the eastern hemisphere. The eastern hemisphere is shown here. The REE-mineral associations and their chemical characteristics are discussed in the main text. The area outlined by the red box can be viewed at a smaller scale in the Supplementary Information. (b) Summary of the global distribution of major REE resources associated with alkali igneous deposits ( $n=100$, for 22 deposits no specific REE mineralogy is reported) [11,28] for the western hemisphere. The REE-mineral associations and their chemical characteristics are discussed in the main text.

As shown, REE-mineral occurrences within the context of the deposits summarized are documented on every continent with the exception of Antarctica. Sixty different REE-bearing minerals have been reported from these deposits, 33 of which occur only in a single location (Figure 3a,b; their chemical formulae are provided in Table 1). It is noted here however, that these world-wide occurrences and associated mineral distributions may simply be a function of a lack of exploration and should not be taken as evidence of absence. Figure 3 a summarizes the relative occurrences of the 20 most abundant REE-bearing minerals reported. Minerals of the monazite, eudialyte, bastnäsite, and allanite groups are the most common, found in $39,33,32$, and 32 deposits respectively. 
(a)

(b)

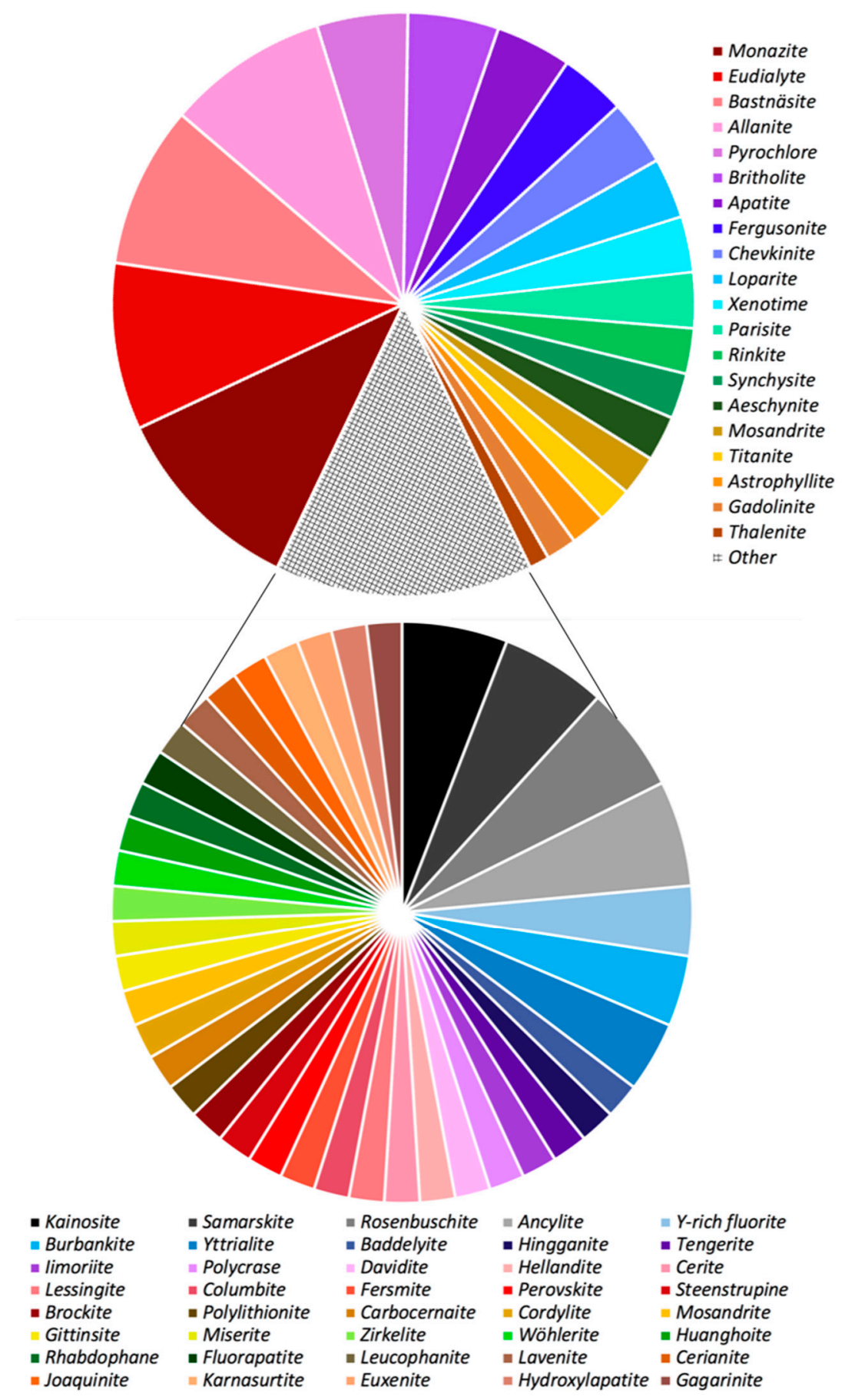

Figure 3. A total of 60 REE-bearing minerals and mineral groups have been reported for the deposits summarized in Figure 2 [28]. Upper panel (a) graphic illustrating the relative presence of the top 20 REE-bearing minerals and mineral groups found in the deposits summarized in Table 1. Monazite group minerals are the most commonly occurring REE-bearing minerals, present in 39 of the deposits (Table 1) with minerals of the eudialyte, bastnäsite, and allanite groups found in 33, 32, and 32 of the reported deposits respectively. Gadolinite and thalenite, the 2 least common occurring of the top 20, are reported in 6 and 4 deposits respectively. Lower panel (b) graphic summarizing the relative occurrence of the other 40 REE-bearing minerals reported to be associated with the deposits summarized in Table 1. 33 of these are reported only once. Members of the kainosite, samarskite, rosenbuschite, and ancylite groups are reported three times, with Y-rich fluorite, burbankite, and yttrialite each reported twice. 
Table 1. Minerals and/or mineral groups reported for the deposits shown in Figure 2. *: Mineral names, their abbreviations [29,30] (see Supplementary Information) and their formulae. Unless otherwise indicated, mineral formulae from [31,32].

\begin{tabular}{|c|c|c|c|c|c|}
\hline Mineral (Group) & Abv. & Formula & Mineral (Group) & Abv. & Formula \\
\hline Aeschynite & Aes & $\mathrm{AD}_{2} \mathrm{O}_{6}(\mathrm{~A}=\mathrm{Y}, \mathrm{REE}, \mathrm{Ca}, \mathrm{I}$, and $\mathrm{Th} ; \mathrm{D}=\mathrm{Ti}, \mathrm{Nb}, \mathrm{Ta})$ & Joaquinite & Joa & $\mathrm{NaBa}_{2} \mathrm{Ce}_{2} \mathrm{FeTi}_{2}\left[\mathrm{Si}_{4} \mathrm{O}_{12}\right]_{2} \mathrm{O}_{2}(\mathrm{OH}, \mathrm{F}) \cdot \mathrm{H}_{2} \mathrm{O}$ \\
\hline Allanite & $A l n *$ & $\left\{\mathrm{~A}^{2+}{ }^{2+} \mathrm{REE}^{3+}\right\}\left\{\mathrm{M}^{3+}{ }_{2} \mathrm{M}^{2+}\right\}\left(\mathrm{Si}_{2} \mathrm{O}_{7}\right)\left(\mathrm{SiO}_{4}\right) \mathrm{O}(\mathrm{OH})$ & Karnasurtite & Kar & $(\mathrm{Ce}, \mathrm{La}, \mathrm{Th})(\mathrm{Ti}, \mathrm{Nb})(\mathrm{Al}, \mathrm{Fe})\left(\mathrm{Si}_{2} \mathrm{O}_{7}\right)(\mathrm{OH})_{4} \cdot 3 \mathrm{H}_{2} \mathrm{O}$ \\
\hline Ancylite & $A n c$ & $\mathrm{Sr}(\mathrm{La}, \mathrm{Ce})\left(\mathrm{CO}_{3}\right)_{2}(\mathrm{OH}) \cdot\left(\mathrm{H}_{2} \mathrm{O}\right)$ & Kainosite & Kai & $\mathrm{Ca}_{2}(\mathrm{Y}, \mathrm{Ce})_{2} \mathrm{Si}_{4} \mathrm{O}_{12}\left(\mathrm{CO}_{3}\right)\left(\mathrm{H}_{2} \mathrm{O}\right)$ \\
\hline Apatite & $A p^{*}$ & $(\mathrm{Ca}, \mathrm{REE})_{5}\left(\mathrm{PO}_{4}\right)_{3}(\mathrm{OH}, \mathrm{F}, \mathrm{Cl})$ & Leucophanite [33] & Leu & $\mathrm{Na}(\mathrm{Ca}, \mathrm{REE}) \mathrm{BeSi}_{2} \mathrm{O}_{6} \mathrm{~F}^{+}$ \\
\hline Astrophyllite [34] & Ast & $(\mathrm{K}, \mathrm{Na}, \mathrm{REE})_{3}(\mathrm{Fe}, \mathrm{Mn})_{7} \mathrm{Ti}_{2}\left(\mathrm{Si}_{4} \mathrm{O}_{12}\right)_{2}(\mathrm{O}, \mathrm{OH}, \mathrm{F})_{7}$ & Loparite & Lop & $(\mathrm{Ce}, \mathrm{Na}, \mathrm{Ca})_{2}(\mathrm{Ti}, \mathrm{Nb})_{2} \mathrm{O}_{6}$ \\
\hline Bastnäsite & Bas & $(\mathrm{REE})\left(\mathrm{CO}_{3}\right) \mathrm{F}$ & Miserite & Mis & $\mathrm{K}_{1.5 \mathrm{x}}(\mathrm{Ca}, \mathrm{Y}, \mathrm{REE})_{5}\left(\mathrm{Si}_{6} \mathrm{O}_{15}\right)\left(\mathrm{Si}_{2} \mathrm{O}_{7}\right)(\mathrm{OH}, \mathrm{F})_{2} \cdot \mathrm{yH}_{2} \mathrm{O}$ \\
\hline Britholite & Bri & $(\mathrm{Ce}, \mathrm{Ca}, \mathrm{Th}, \mathrm{La}, \mathrm{Nd})_{5}\left(\mathrm{SiO}_{4}, \mathrm{PO}_{4}\right)_{3}(\mathrm{OH}, \mathrm{F})$ & Monazite & $M n z^{*}$ & $(\mathrm{La}, \mathrm{Ce}, \mathrm{Sm}, \mathrm{Nd}) \mathrm{PO}_{4}$ \\
\hline Brockite & Bro & $(\mathrm{Ca}, \mathrm{Th}, \mathrm{Ce})\left(\mathrm{PO}_{4}\right) \cdot\left(\mathrm{H}_{2} \mathrm{O}\right)$ & Mosandrite & Mos & $\mathrm{Na}(\mathrm{Na}, \mathrm{Ca})_{2}(\mathrm{Ca}, \mathrm{Ce}, \mathrm{Y})_{4}(\mathrm{Ti}, \mathrm{Nb}, \mathrm{Zr})\left(\mathrm{Si}_{2} \mathrm{O}_{7}\right)_{2}(\mathrm{O}, \mathrm{F})_{2} \mathrm{~F}_{3}$ \\
\hline Burbankite [35] & Bur & $(\mathrm{Na}, \mathrm{Ca})_{3}(\mathrm{Sr}, \mathrm{REE}, \mathrm{Ba})_{3}\left(\mathrm{CO}_{3}\right)_{5}$ & Parisite & Par & $\mathrm{Ca}(\mathrm{Ce}, \mathrm{La})_{2}\left(\mathrm{CO}_{3}\right)_{3} \mathrm{~F}_{2}$ \\
\hline Carbocernaite & Car & $(\mathrm{Ca}, \mathrm{Na})(\mathrm{Sr}, \mathrm{Ce}, \mathrm{Ba})\left(\mathrm{CO}_{3}\right)_{2}$ & Perovskite & $\operatorname{Pro}{ }^{*}$ & $(\mathrm{Ca}, \mathrm{REE}) \mathrm{TiO}_{3}$ \\
\hline Cerianite & Cer & $\left(\mathrm{Ce}^{4+}, \mathrm{Th}\right) \mathrm{O}_{2}$ & Polycrase & Pol & $(\mathrm{Y}, \mathrm{Ca}, \mathrm{Ce}, \mathrm{U}, \mathrm{Th})(\mathrm{Ti}, \mathrm{Nb}, \mathrm{Ta})_{2} \mathrm{O}_{6}$ \\
\hline Cerite & Crt & $(\mathrm{La}, \mathrm{Ce}, \mathrm{Ca})_{9}\left(\mathrm{Mg}, \mathrm{Fe}^{3+}\right)\left(\mathrm{SiO}_{4}\right)_{6}\left[\mathrm{SiO}_{3}(\mathrm{OH})\right](\mathrm{OH})_{3}$ & Pyrochlore & $\mathrm{PCl}^{*}$ & $(\mathrm{Na}, \mathrm{Ca}, \mathrm{REE})_{2} \mathrm{Nb}_{2} \mathrm{O}_{6}(\mathrm{OH}, \mathrm{F})$ \\
\hline Chevkinite & Che & $(\mathrm{Ce}, \mathrm{La}, \mathrm{Ca}, \mathrm{Th})_{4}\left(\mathrm{Fe}^{2+}{ }^{2} \mathrm{Mg}\right)_{2}\left(\mathrm{Ti}_{1} \mathrm{Fe}^{3+}\right)_{3} \mathrm{Si}_{4} \mathrm{O}_{22}$ & Rhabdophane & Rha & $(\mathrm{Ce}, \mathrm{La}) \mathrm{PO}_{4} \cdot\left(\mathrm{H}_{2} \mathrm{O}\right)$ \\
\hline Cordylite & Cor & $\mathrm{Ba}(\mathrm{Ce}, \mathrm{La})_{2}\left(\mathrm{CO}_{3}\right)_{3} \mathrm{~F}_{2}$ & Rinkite & Rin & $\mathrm{Na}(\mathrm{Na}, \mathrm{Ca})_{2}(\mathrm{Ca}, \mathrm{Ce})_{4}(\mathrm{Ti}, \mathrm{Nb})\left(\mathrm{Si}_{2} \mathrm{O}_{7}\right)_{2}(\mathrm{O}, \mathrm{F})_{2}$ \\
\hline Davidite & Dav & $(\mathrm{La}, \mathrm{Ce}, \mathrm{Ca})(\mathrm{Y}, \mathrm{U})\left(\mathrm{Ti}, \mathrm{Fe}^{3+}\right)_{20} \mathrm{O}_{38}$ & Rosenbuschite & Ros & $(\mathrm{Ca}, \mathrm{Na}, \mathrm{REE})_{3}(\mathrm{Zr}, \mathrm{Ti}) \mathrm{Si}_{2} \mathrm{O}_{8} \mathrm{~F}$ \\
\hline Eudialyte & Eud * & $\mathrm{Na}_{4}(\mathrm{Ca}, \mathrm{Ce})_{2}\left(\mathrm{Fe}^{2+} \mathrm{Mn}, \mathrm{Y}\right) \mathrm{ZrSi}_{8} \mathrm{O}_{22}(\mathrm{OH}, \mathrm{Cl})_{2}$ & Samarskite & Sam & $\left(\mathrm{Yb}, \mathrm{Y}, \mathrm{REE}, \mathrm{U}, \mathrm{Th}, \mathrm{Ca}, \mathrm{Fe}^{2+}\right)(\mathrm{Nb}, \mathrm{Ta}, \mathrm{Ti}) \mathrm{O}_{4}$ \\
\hline Euxenite & Eux* & $(\mathrm{Y}, \mathrm{Ca}, \mathrm{Ce}, \mathrm{U}, \mathrm{Th})(\mathrm{Nb}, \mathrm{Ta}, \mathrm{Ti})_{2} \mathrm{O}_{6}$ & Steenstrupine & Ste & $\mathrm{Na}_{14} \mathrm{Ce}_{6} \mathrm{Mn}^{2+} \mathrm{Mn}^{3+} \mathrm{Fe}^{2+}{ }_{2} \mathrm{ZrTh}\left(\mathrm{Si}_{6} \mathrm{O}_{18}\right)_{2}\left(\mathrm{PO}_{4}\right)_{7} \cdot 3\left(\mathrm{H}_{2} \mathrm{O}\right)$ \\
\hline Fergusonite & Fer & $(\mathrm{Y}, \mathrm{Ce}, \mathrm{Nd}) \mathrm{NbO}_{4}$ & Synchysite & Syn & $\mathrm{Ca}(\mathrm{Ce}, \mathrm{Nd}, \mathrm{Y})\left(\mathrm{CO}_{3}\right)_{2} \mathrm{~F}$ \\
\hline Fersmite & Fes & $(\mathrm{Ca}, \mathrm{Ce}, \mathrm{Na})(\mathrm{Nb}, \mathrm{Ta}, \mathrm{Ti})_{2}(\mathrm{O}, \mathrm{OH}, \mathrm{F})_{6}$ & Tengerite & Ten & $\mathrm{Y}_{2}\left(\mathrm{CO}_{3}\right)_{3} \cdot 2-3 \mathrm{H}_{2} \mathrm{O}$ \\
\hline Gadolinite & Gad & $(\mathrm{Ce}, \mathrm{La}, \mathrm{Nd}, \mathrm{Y})_{2} \mathrm{Fe}^{2+} \mathrm{Be}_{2} \mathrm{Si}_{2} \mathrm{O}_{10}$ & Thalenite & Tha & $\mathrm{Y}_{3} \mathrm{Si}_{3} \mathrm{O}_{10}(\mathrm{OH})$ \\
\hline Gagarinite & Gag & $\mathrm{Na}\left(\mathrm{REE}_{\mathrm{x}} \mathrm{Ca}_{1-\mathrm{x}}\right)\left(\mathrm{REE}_{\mathrm{y}} \mathrm{Ca}_{1-\mathrm{y}}\right) \mathrm{F}_{6}$ or $\mathrm{NaCaYF}_{6}$ (the $Y$-variety) & Titanite & Ttn & $\mathrm{CaREETiSiO}_{5}$ \\
\hline Hellandite & $\mathrm{Hel}$ & $(\mathrm{Ca}, \mathrm{REE})_{4} \mathrm{Ce}_{2} \mathrm{Al}[]_{2}\left(\mathrm{~B}_{4} \mathrm{Si}_{4} \mathrm{O}_{22}\right)(\mathrm{OH})_{2}$ & Wöhlerite [36] & Woh & $\mathrm{NaCa}_{2}(\mathrm{Zr}, \mathrm{Nb}) \mathrm{Si}_{2} \mathrm{O}_{7}(\mathrm{O}, \mathrm{OH}, \mathrm{F})_{2}$ \\
\hline Hingannite & Hig & $\mathrm{Y}_{2}([\mathrm{REE}]) \mathrm{Be}_{2} \mathrm{Si}_{2} \mathrm{O}_{8}(\mathrm{OH})_{2}$ & Xenotime & $X n m *$ & $\mathrm{YPO}_{4}$ \\
\hline Huangoite-(Ce) & Ниа & $\mathrm{BaCe}\left(\mathrm{CO}_{3}\right)_{2} \mathrm{~F}$ & Y-rich fluorite & $Y-f$ & $\left(\mathrm{Ca}_{1-\mathrm{x}} \mathrm{Y}_{\mathrm{x}}\right) \mathrm{F}_{2+\mathrm{x}}$ where $0.05<\mathrm{x}<0.3$ \\
\hline Iimoriite & Iim & $\mathrm{Y}_{2}\left(\mathrm{SiO}_{4}\right)\left(\mathrm{CO}_{3}\right)$ & Zirkelite & Zir & $(\mathrm{Ti}, \mathrm{Ca}, \mathrm{Zr}) \mathrm{O}_{2-x}$ \\
\hline
\end{tabular}


With respect to the specific REEs the monazite, eudialyte, bastnäsite, and allanite mineral groups host in these environments, these minerals are all characterized by LREE enrichment (Figure 4). All the REEs in these minerals are present in abundances greater than that of chondrite, with La in bastnäsite present at $10^{6}$ times greater than a chondritic geochemical reservoir. The overall shape of the REE patterns in these minerals is reflected in their normalized elemental ratios, with the steep nature of bastnäsite minerals reflected in their high $\mathrm{La}_{N} / \mathrm{Yb}_{\mathrm{N}}$ and $\mathrm{La}_{N} / \mathrm{Sm} \mathrm{m}_{\mathrm{N}}$ values (a LREE/HREE and LREE/MREE comparison, $>6000$ and $>15$ respectively, Figure $4 \mathrm{~b}$ ) compared to the relatively flat nature of the minerals from the eudialyte group, where $\mathrm{La}_{\mathrm{N}} / \mathrm{Yb}_{\mathrm{N}}$ values are $<8$ and $\mathrm{La}_{\mathrm{N}} / \mathrm{Sm}_{\mathrm{N}}$ values are $>5$ (Figure $4 \mathrm{~b}$ ). Minerals of the allanite and monazite groups exhibit similar profiles (Figure $4 \mathrm{a}$ ) with similar $\mathrm{La}_{\mathrm{N}} / \mathrm{Sm}_{\mathrm{N}}$ values to those of the eudialyte group at $<10$ but generally stronger partitioning between the LREE and HREE with $\mathrm{La}_{\mathrm{N}} / \mathrm{Yb}_{\mathrm{N}}$ values from $\sim 230$ to $~ 380$ and $\sim 100$ to $\sim 220$ respectively (with the exception of one monazite-(Ce) grain shown in Figure $4 \mathrm{~b}$ where $\mathrm{La}_{\mathrm{N}} / \mathrm{Yb}_{\mathrm{N}}=364$ ). From Figure $3 \mathrm{a}$, the next two most commonly reported REE-bearing minerals in the deposits shown in Figure 2 are those of the pyrochlore and britholite groups.
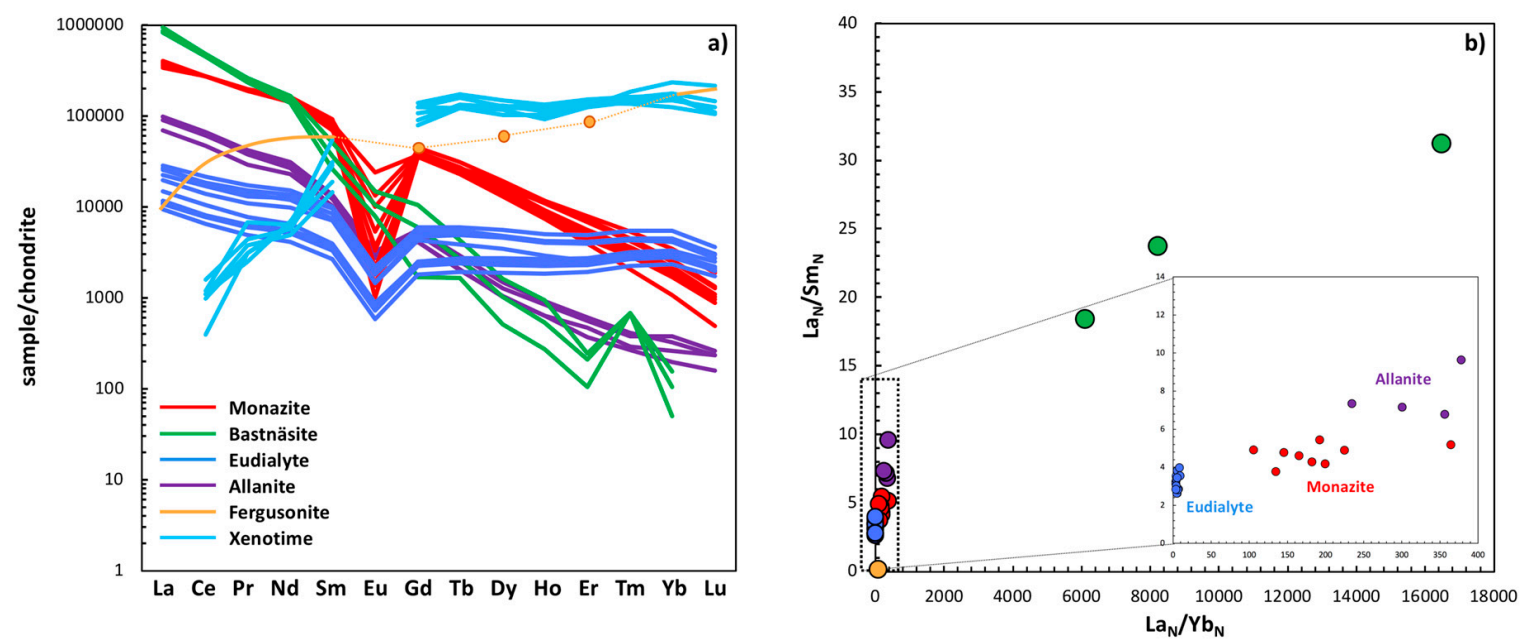

Figure 4. (a) Chondrite normalized $\left(_{\mathrm{N}}\right)$ REE profiles for representative examples of minerals of the monazite, bastnäsite, eudialyte, and allanite groups illustrating their broadly LREE enriched nature, and minerals of the fergusonite and xenotime groups, illustrating their broadly HREE-enriched nature. (b) Degree of LREE enrichment highlighted, particularly for bastnäsite-(Ce) with values of $>6000$ for LREE/HREE signatures [37-41]. The $y$-axis shows $\mathrm{La}_{N} / \mathrm{Sm}_{\mathrm{N}}$ where $\mathrm{Sm}$ was selected to represent the middle rare earths. Normalization values reported in Sun and McDonough [42].

Both of these mineral groups are also LREE-enriched, as are the minerals from the apatite group, one of the next most abundant found in 15 of the deposits (Figure 2). The most common occurring HREE-enriched mineral is fergusonite-(Y), present in 13 of the deposits (Figure 4a). From Figure $4 b$, LREE/HREE values in fergusonite- $(\mathrm{Y})$ are as low as $0.059\left(\mathrm{La}_{\mathrm{N}} / \mathrm{Yb}_{\mathrm{N}}\right)$ with correspondingly low LREE/MREE values at $0.157\left(\mathrm{La}_{\mathrm{N}} / \mathrm{Yb}_{\mathrm{N}}\right)$ and absolute abundances of HREEs several orders of magnitude greater than those from representative examples from the bastnäsite and eudialyte groups, e.g., $\mathrm{Yb}$ and $\mathrm{Lu}$ in fergusonite- $(\mathrm{Y})$ are reported at 36,539 ppm and $8642 \mathrm{ppm}$ respectively. This is compared to an average of abundance of $23 \mathrm{ppm}$ in bastnäsite group minerals and of $733 \mathrm{ppm}$ and $89 \mathrm{ppm}$ for $\mathrm{Yb}$ and $\mathrm{Lu}$ in common members of the eudialyte group respectively [39,40]. Members from the chevnikite group in these environments are also present in 13 of the documented deposits and tend to be LREE-enriched with $\mathrm{La}_{\mathrm{N}} / \mathrm{Sm}_{\mathrm{N}}$ ranging from 10 to 17 and absolute abundances of La up to $12,100 \mathrm{ppm}$ [43] (no $\mathrm{Yb}$ data presented). Loparite-(Ce) is the next most abundant mineral of the deposits shown in Figure 2, present in 12 of the REE associations, and also a LREE-enriched mineral with $\mathrm{La}_{\mathrm{N}} / \mathrm{Yb}_{\mathrm{N}}$ at $\sim 34$, and $\mathrm{La}_{\mathrm{N}} / \mathrm{Yb}_{\mathrm{N}}$ at $\sim 11$ [44]. Xenotime-(Y), present in 11 of the deposits, is the second most abundant HREE-rich mineral shown in Figure 3a. Xenotime-(Y) (HREE-enriched phase) 
is characterized by steep LREE/MREE patterns [45] with $\mathrm{Ce}_{\mathrm{N}} / \mathrm{Sm}_{\mathrm{N}}$ ranging from 0.007 to 0.073 and LREE/HREE from 0.003 to 0.008 with up to $~ 51,300 \mathrm{ppm} \mathrm{Yb}$ (and $~ 8200 \mathrm{ppm}$ of Lu, Figure 2b). With respect to the absolute abundance of HREEs, these are present at similar orders of magnitude than the other HREE mineral discussed earlier, fergusonite-(Y), with only two of the deposits in Figure 2 containing both of these HREE-enriched phases (the deposits at Amis and Bokan). Of the remaining nine minerals shown in Figure 3a, four are LREE-enriched phases, mosandrite-(Ce) for example with $\mathrm{La}_{\mathrm{N}} / \mathrm{Yb}_{\mathrm{N}} \sim 13$ and $\mathrm{La}_{\mathrm{N}} / \mathrm{Sm}_{\mathrm{N}}$ at 8.3 [46], in addition to minerals of the parisite, rinkite, and synchysite groups. Three are MREE-enriched, some of the aeschynite group for example with $\mathrm{La}_{\mathrm{N}} / \mathrm{Yb}_{\mathrm{N}}$ at 1.1-5.6 and $\mathrm{La}_{\mathrm{N}} / \mathrm{Sm}_{\mathrm{N}}$ at 0.3-0.6 [47], as well as titanite and cases in the gadolinite group. The remaining two are HREE-enriched (astrophyllite and thalenite groups) with the latter exhibiting low REE normalized ratios: e.g., $\mathrm{Ce}_{\mathrm{N}} / \mathrm{Yb}_{\mathrm{N}} \sim 0.02$ and $\mathrm{Ce}_{\mathrm{N}} / \mathrm{Sm}_{\mathrm{N}}$ at $\sim 0.08$ [48]. The remaining 40 minerals shown in Figure $5 b$ are mentioned $\leq 3$ times throughout the deposits shown in Figure 2 with 4 described three times, 3 described twice, and 33 found only once. The majority of the deposits shown in Figure 4 report the occurrence of between one and four of the minerals shown in Figure 3. This is summarized in Figure 5.

As shown in Figure 5, 25 of the deposits considered here report the occurrence of only a single REE-bearing phase. Of those 25, 19 report the sole occurrence of one of the most commonly occurring REE minerals throughout all the deposits (Figure 3a) with 9 deposits containing minerals of the eudialyte group, four hosting bastnäsite group representatives, three hosting examples of the monazite group, and three hosting members of the allanite group. Two of the deposits report REE-rich members of the apatite group with the following reported only once throughout those 25: fergusonite-(Y), britholite-(Ce), and members of the pyrochlore group.

As has been discussed, the mineralogy of chemically evolved magmatic systems is diverse within the context of exploring potential REE-bearing deposits (Figures 2 and 3). To date however, few of these reported phases have been successfully extracted at an economically justifiable commercial scale.

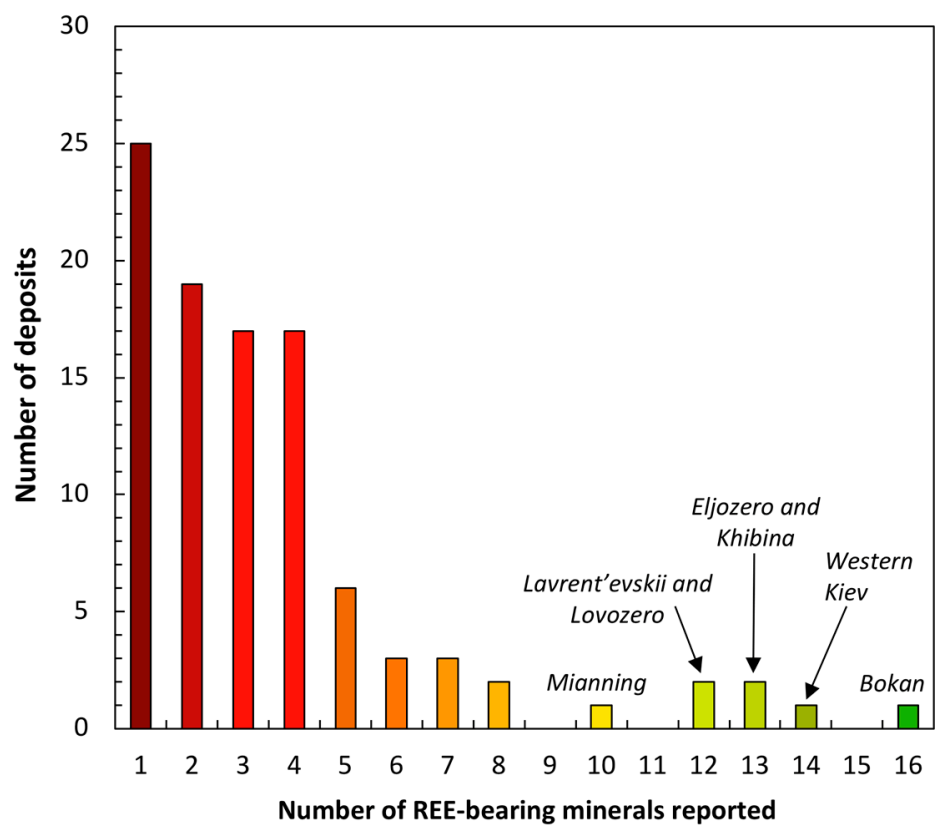

Figure 5. Graphic summarizing the occurrence of REE-bearing minerals of economic interest that have been reported in the deposits illustrated in Figure 2 [28]. Twenty-one of the deposits report the occurrence of $\geq 5$ REE minerals, 34 contain three or four REE minerals, and 44 of the deposits report only one or two REE minerals.

Figure 6 summarizes the total REO\% (total rare earth oxide) associated with the most commonly occurring REE-bearing phases in the deposits shown in Figure 2. Minerals of the bastnäsite, monazite, 
and xenotime groups are shown to contain some of the highest percentages of total REOs. Minerals of the bastnäsite group exhibit the highest REO abundances up to $75 \mathrm{wt} \%$, with minerals of the monazite group up to $71 \mathrm{wt} \%$ but with an acknowledged range down to lower abundances at $35 \mathrm{wt} \%$ [49]. By comparison, minerals of the xenotime group contain a relatively short range of REO\% abundances from $52 \%$ to $61 \%$ although this is primarily accounted for by the HREE and Y. Other high total REO\% phases include thalenite-(Y) (up to $64 \mathrm{wt} \%$ ), members of the parasite group and members of the britholite group both up to $50 \mathrm{wt} \%$ and members of the gadolinite group up to $60 \mathrm{wt} \%$ (Figure 6).

Members of the bastnäsite and monazite groups are LREE-enriched in most of the study environments (Figure $4 \mathrm{a}, \mathrm{b}$ ) and are predominantly mined to meet the demand for $\mathrm{La}, \mathrm{Ce}, \mathrm{Pr}$, and $\mathrm{Sm}$. For example [49,50], battery alloys require (of the total REEs required) $50 \% \mathrm{La}, 33.4 \% \mathrm{Ce}, 10 \% \mathrm{Nd}$, and 3.3\% Pr while processes associated with the refinement of petroleum require up to $90 \% \mathrm{La}$. Some of the more common uses of $\mathrm{Ce}$ are in glass additives (66\%), polishing compounds (65\%), and metal alloys (52\%). The biggest use of $\mathrm{Pr}$ is in magnets $(23.4 \%)$, as is the use of $\mathrm{Nd}(69.4 \%)$.

Minerals of the xenotime group are HREE enriched (Figure 4a), contain significantly less LREEs than those of the bastnäsite or monazite groups, but are often found in association with monazite. With respect to the deposits in Figure 2, 41 of the deposits contain either minerals of the xenotime or monazite groups. With respect to uses of the HREEs, Ho, Er, and $\mathrm{Yb}$ are widely used in lasers with almost every HREE used in the production of (metal) alloys. Other notable applications include the use of $\mathrm{Tm}$ in the manufacturing of euro banknotes as a counterfeit measure, $\mathrm{Yb}$ in the development of earthquake detectors, and Er in camera filters [51-53].

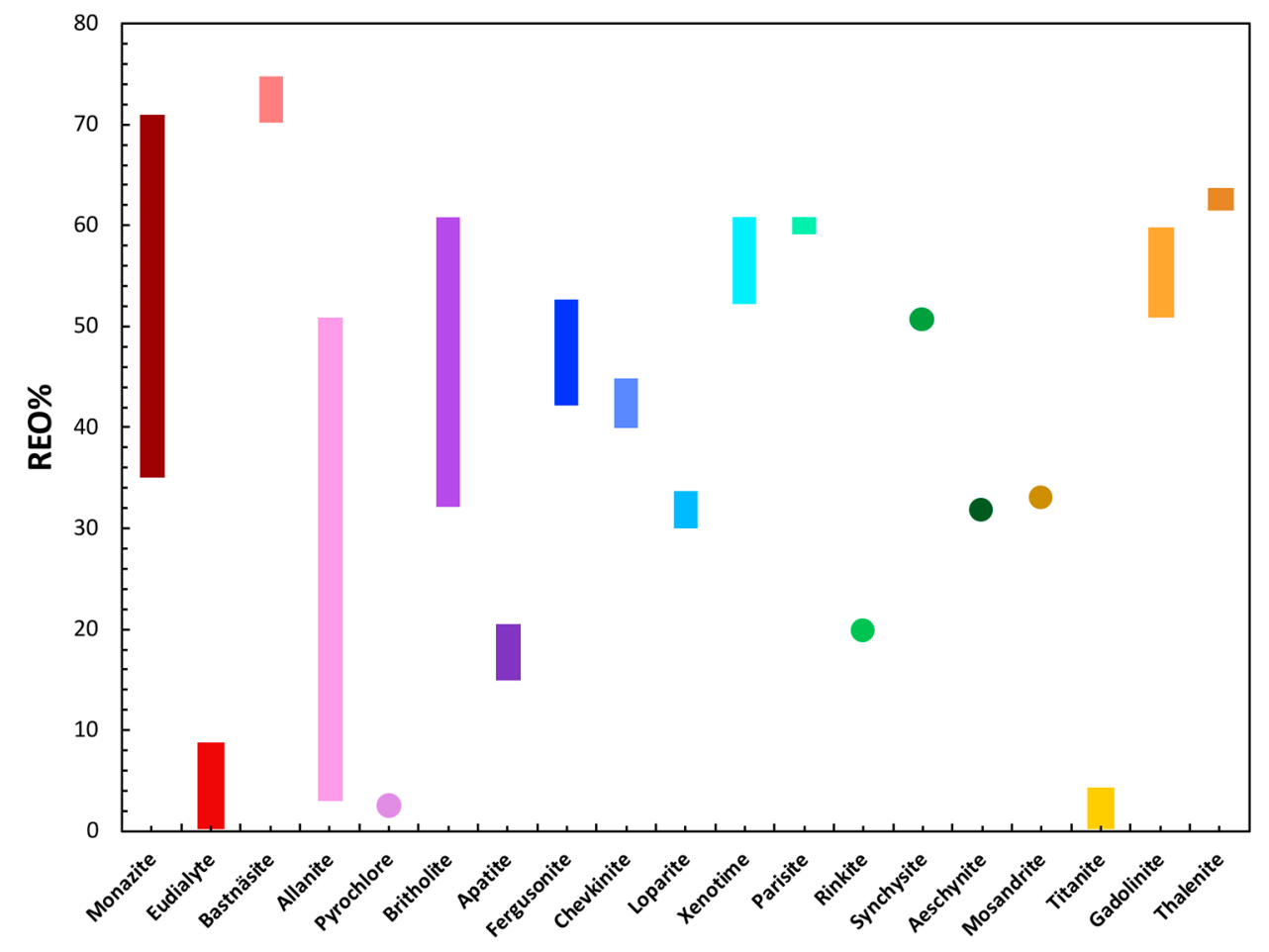

Figure 6. Graphic summarizing the range in REO\% in each of the phases shown in Figure 3a (with the exception of astrophyllite for which no data in the literature could be found) [11,50-52].

Despite the wide use of the REEs in everyday objects (e.g., televisions, cars), in the development of renewable energy sources (e.g., wind turbines), in the medical field (e.g., MRI systems), and in military-based technologies, they are not unlimited resources [19]. At present, current efforts to recycle them are limited with less than $1 \%$ of REEs recycled [54,55]. In part, this is related to the challenges faced in recycling the REEs due to their initial high market price, difficulty associated with the technology required to make this approach economic, and the lack of incentives to do so [55]. 
With several of the REEs having $<2000$ years of reserves left based on current understanding of Earth's bulk crust composition (Figure 1), market demands, and their geological associations, it is inevitable that one day the supply of REEs on Earth will run out. It is therefore natural to consider other potentially viable options and locations for future resource exploration $[19,56]$.

\section{REEs on the Earth's Moon: The KREEP Reservoir}

The Earth's moon is our nearest neighbor in space. Like the Earth, the Moon underwent metal-silicate partitioning during early planetary differentiation. This established the lunar architecture observed today where the Moon is characterized by an inner and outer core, a mantle, and a crust [57]. The geological history of the Moon is arguably simpler than the Earth due to the absence of plate tectonics and the processes that work to resurface and metamorphose lunar lithologies are predominantly associated with impacts. Following a collision between proto-Earth and a Mars-sized object (Theia) early in the history of the Solar System, the Earth's moon formed (likely within the first 70 to $100 \mathrm{Myr}$ of Solar System evolution) [58-71]. Crystallization of the newly formed planetary body has been explained through the lunar magma ocean (LMO) model following the return of Apollo samples in the late 1960s and 1970s and the observation of complementary geochemical signatures in different lunar lithologies (the mare basalts and the feldspathic lunar crust [62,63]). The LMO model describes the progressive solidification of an initially molten body, the formation of the lunar mantle and crust, and the establishment of geochemically distinct reservoirs within the lunar interior. Figure 7 summarizes the later stages of lunar differentiation, following 99\% solidification and the production of the potassium (K)-rare earth element (REE)-phosphorus (P, or KREEP) reservoir, the chemical signatures of which have been identified throughout the lunar sample collection.

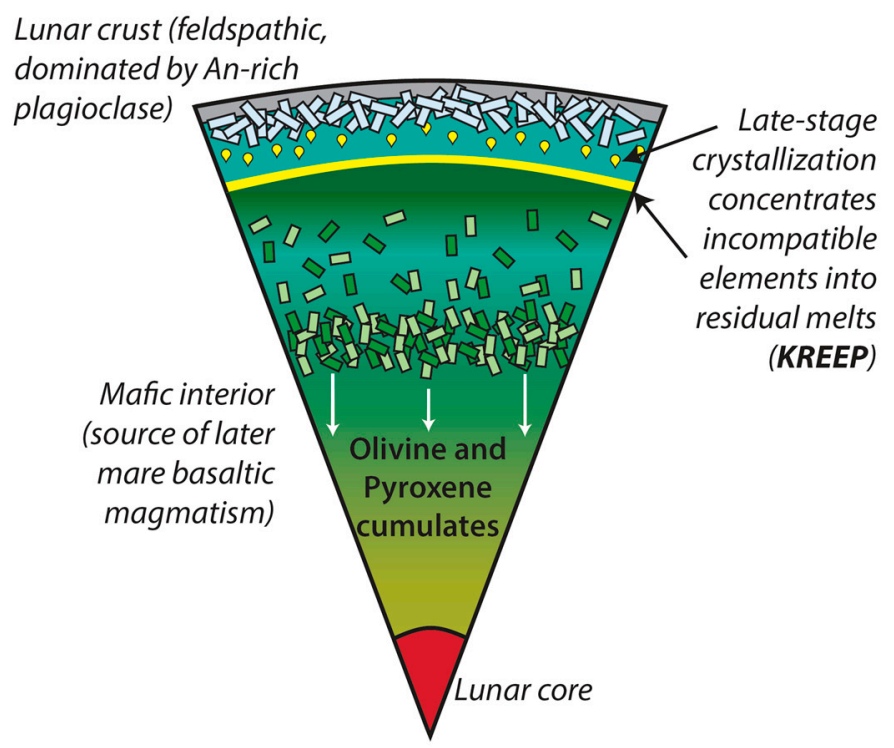

Figure 7. Simplified model of lunar magma ocean solidification where by early crystallization is characterized by olivine and pyroxene which settle towards the lunar interior [19,62-64]. When plagioclase becomes a liquidus phase, it buoyantly rises to the top of the cooling LMO to form a primary, anorthositic, flotation crust. Incompatible elements in these major rock forming minerals, e.g., the REEs, are concentrated in late-stage residual liquids and form the KREEP reservoir.

The lunar crust is chemically similar, at least with respect to several of its major element signatures, to Earth's. This is summarized in Figure 8 where the lunar highlands and lowlands are shown separately. The lunar highlands are the lighter regions of the lunar surface, typically characterized by anorthositic (Ca-rich feldspar) material. "The lunar lowlands" refers to the flat plain regions which are, but not always, covered by the lunar basaltic maria (the name "maria" stems from the latin word for "seas"). Silicon and O dominate the planetary crusts of both the Moon and the Earth with Si/O 
values from 0.47 (highlands) to 0.59 (Earth) [65]. The Fe/Mg ratios differ significantly between the highlands and lowlands, as expected from the predominance of the lunar mare in the lowlands (1.07 in the highlands compared to 2.28 in the lowlands and 2.39 on Earth). The lunar regions compared to Earth, lack $\mathrm{Na}$ and $\mathrm{K}$ (Figure 8) but exhibit relatively higher proportions of $\mathrm{Al}$ and $\mathrm{Ca}$, representing the mineralogically simple anorthositic lunar crust.

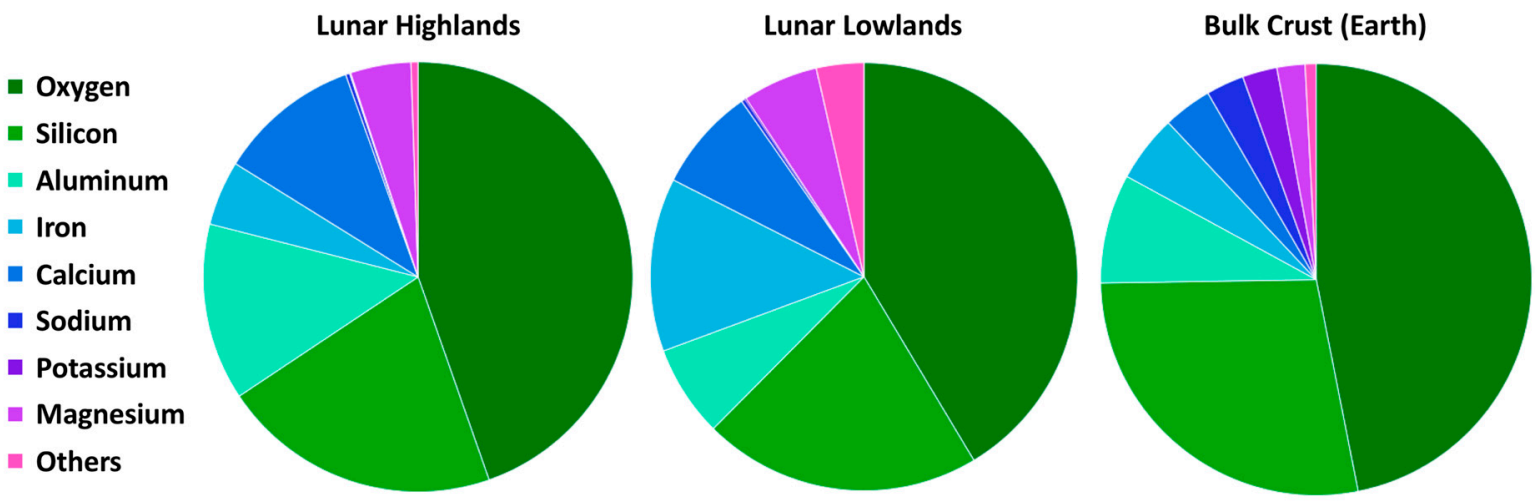

Figure 8. Summary of major element relative abundances in the lunar highlands and lowlands compared to the Earth's crust [65].

Chemically the lunar surface can be divided into three regions (or "crustal terranes" [66]: (1) the Procellerum KREEP Terrane (PKT, Figure 9a), a distinct region in the nearside northern hemisphere enriched in KREEP (Figure 7), Th, U, and incompatible lithophile elements, and which is spatially close to the lunar maria; (2) the feldspar-rich highlands (Figure 8), and (3) the South Pole Aitken (SPA) Terrane on the lunar farside. The SPA refers to a large, $2500 \mathrm{~km}$-diameter impact basin where Fe and Th contents are higher than those across the rest of the lunar farside but are lower than in the nearside PKT (Figure 9a). For the purposes of the discussion to follow, the SPA is not considered any further.

Taken as an average, $80 \%$ of the lunar surface by volume is comprised of anorthitic plagioclase feldspar with regions of the highlands characterized by feldspathic lithologies which contain up to $96 \%$ by volume of feldspar [67]. These feldspathic suites have been inferred to represent potentially primary (or "pristine" [68]) LMO crystallization products. Within the "pristine" classification are three main categories: the ferroan anorthosite suite (or FANs where $\mathrm{Mg} /(\mathrm{Mg}+\mathrm{Fe}$ ) values are low), the magnesian suite (or Mg-suite, where $\mathrm{Mg} /(\mathrm{Mg}+\mathrm{Fe}$ ) values are higher) and the alkali suite. Due to the relatively low abundance of incompatible elements in the FAN lithologies, they are geochemically distinct from the other two categories with the inference that the FAN rocks represent derivation from a primary magma ocean, and the Mg-suite and alkali suite are associated with later lunar magmatism [67] (see Figure 9). Common throughout the Mg-suite, alkali suite, and the later basalts is the presence of the KREEP geochemical signature. Within the Mg-suite exists a wide variety of petrologically distinct lithologies: ultramafics (including dunites and pyroxenites), norites, gabbro norites, and the most abundant Mg-suite lithology, troctolites [69]. The alkali suite rocks, although minor in volume, provide unique insights into late lunar crust evolution. They are petrographically diverse with lithologies ranging from granites and quartz monzodiorites to rhyolites and felsites [70,71]. Figure 9b summarizes the bulk REE signatures of the lunar Mg-suite, alkali suite, KREEP-bearing basalts, and the REE nature of the KREEP geochemical reservoir. These are then compared to bulk crustal reservoirs on Earth and the relatively REE-depleted lunar FAN suite. 

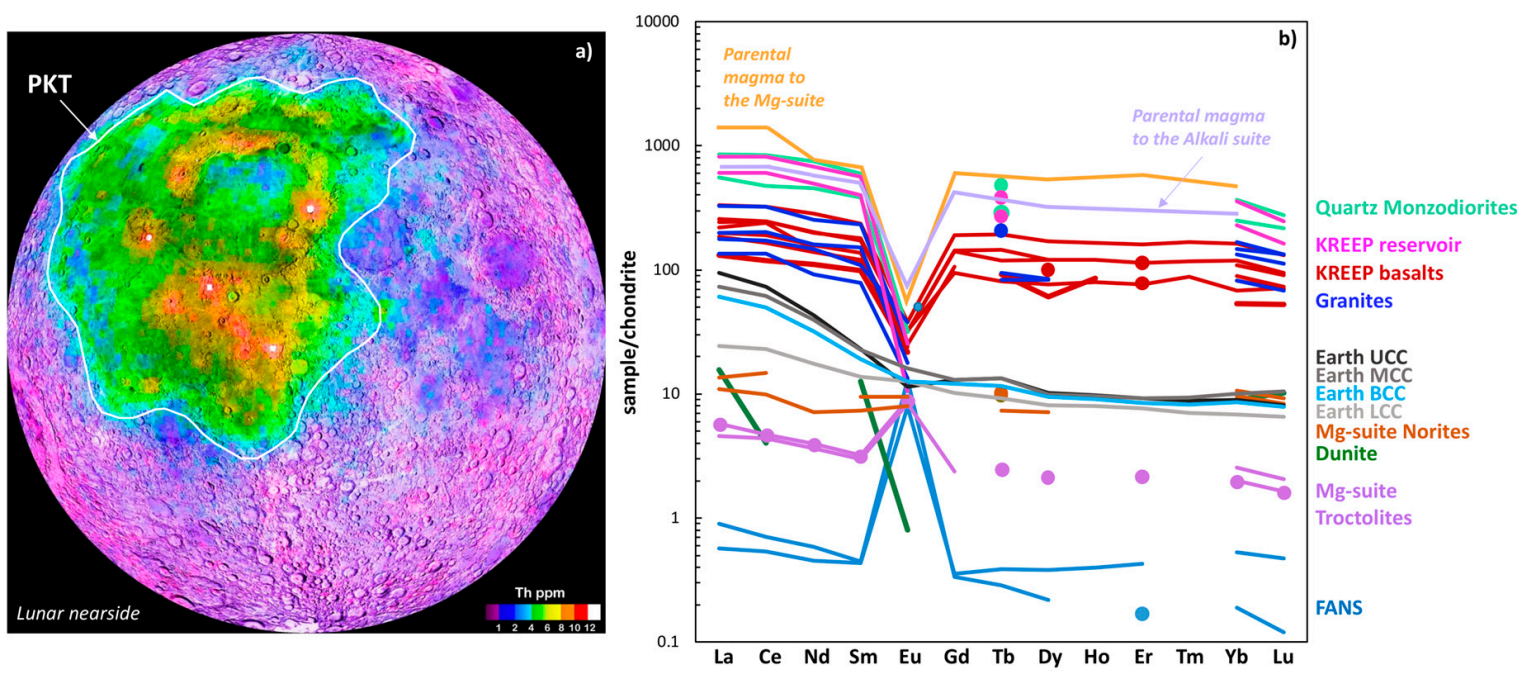

Figure 9. (a) Lunar thorium (Th) map of the nearside [66]. Relatively high concentrations of KREEP-rich lithologies are associated with the occurrence of heat-producing elements (e.g., Th and U) with the area outlined known as the Procellerum KREEP Terrane (or PKT). (b) Summary of chondrite-normalized REE signatures for lunar lithologies, compared to Earth's bulk crustal reservoirs [19,23] (UCC: upper continental crust, MCC: middle continental crust; LCC: lower continental crust; BCC: bulk continental crust). Normalization values reported in Sun and McDonough [42].

Compared to the FAN suite, the Mg-suite is enriched in REEs by approximately an order of magnitude with respect to most elements. For example, absolute abundances of La in the FAN samples shown in Figure 9 range from $0.188 \mathrm{ppm}$ to $0.294 \mathrm{ppm}$, compared to $1.51 \mathrm{ppm}$ to $1.9 \mathrm{ppm}$ and $3.6 \mathrm{ppm}$ to $4.47 \mathrm{ppm}$ for the $\mathrm{Mg}$-suite troctolites and norites respectively. These lithologies, in addition to lunar dunite, exhibit lower REE abundances than the Earth's crustal reservoirs. Relative REE-enrichment in lunar lithologies is demonstrably present in lithologies which show significant geochemical affinity to KREEP. Most notably the lunar KREEP basalts, granites, and quartz monzodiorites. Also shown in Figure $9 \mathrm{~b}$ is the KREEP reservoir (referred to as urKREEP [68,72]), a calculated composition for the KREEP source reservoir [73] (Figure 7), and calculated compositions for the source magmas to the $\mathrm{Mg}$-suite and alkali suites. These compositions have been calculated from in situ analyses of plagioclase in inferred differentiated products from those reservoirs [67] and have $>3$ orders of magnitude higher REE concentrations than the FAN lithologies. The spatial occurrence of the Mg-suite on the Moon appears to be closely associated with the PKT due the occurrence of Mg-suite samples in the returned Apollo samples, the landing sites of which were in, or near the PKT, and the lack of Mg-suite samples in meteorites derived from the lunar highland terranes $[67,70,74,75]$. Although volumetrically less, alkali suite lithologies are also restricted to the PKT, overlapping in age with the Mg-suite (4.3 to $3.8 \mathrm{Ga}$ ) with the KREEP basalts representing some of the youngest alkali magmatism with ages as young as $3.82 \mathrm{Ga}[67]$.

\section{Lunar Granites, REE-Bearing Minerals, and the "Granite Problem"}

Extraterrestrial samples of granite are rare but were first recognized within the returned Apollo breccia samples [76]. This was the first time that evolved, felsic lithologies had been identified on the Moon. Their occurrence is now complemented by more recent remote sensing observations of silicic domes across the lunar surface [77-79]. To date, 22 lunar samples have been classified as granitic in nature, corresponding to $<0.03 \%$ of the total mass of returned Apollo samples [69]. Throughout the Apollo collection, lunar granites exist as clasts within breccias (e.g., Apollo sample 14321 [80-82]), and as lithic fragments in Apollo soil samples (e.g., Apollo sample 12032 [83,84], Figure 10). The majority of lunar granitic samples are fine-grained in nature with the largest grain sizes present in a clast within Apollo breccia sample 15405 (>1 mm grains [84-86]). Hence the term 
'granite' within the context of lunar samples should not be taken to mean the petrographic and textural equivalent of granites on Earth.

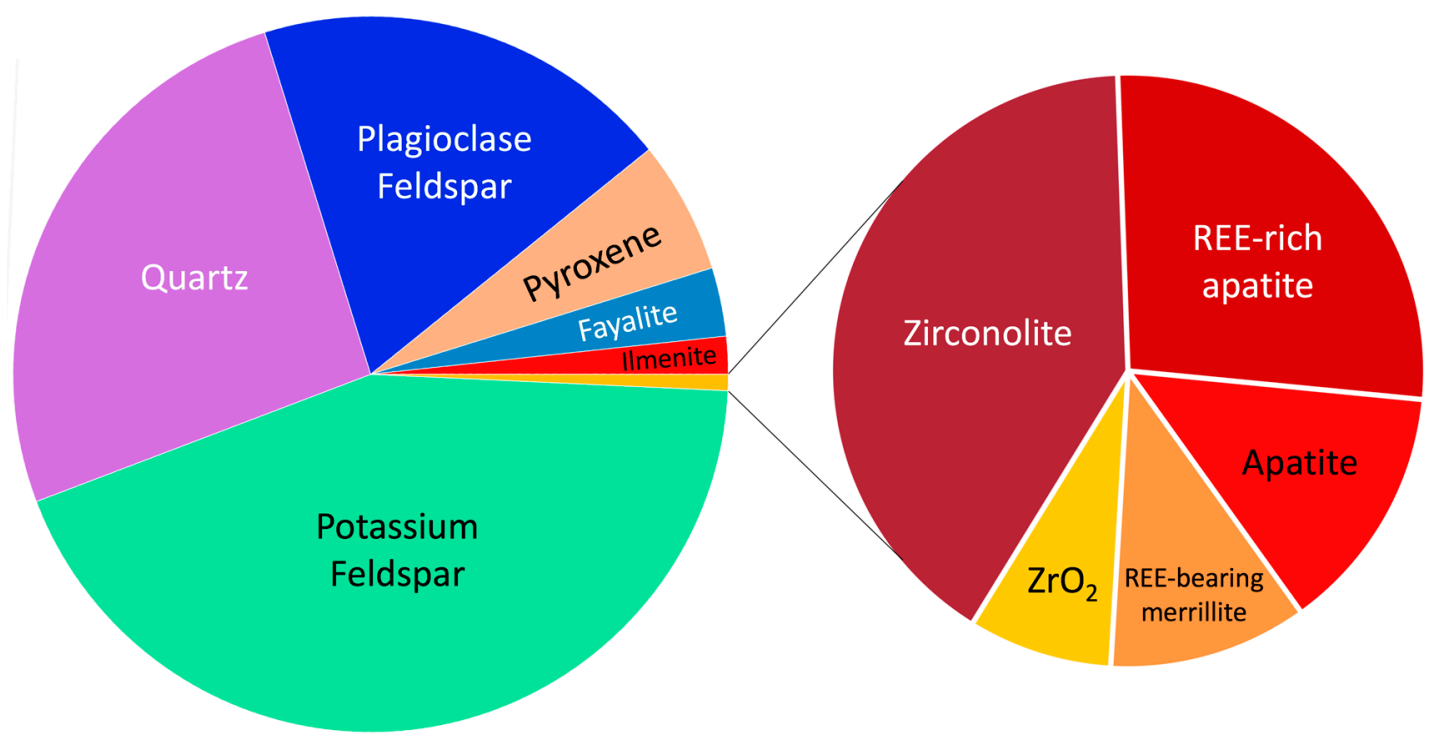

Figure 10. Summary of the relative distribution of the accessory phases from the granite fragment in Apollo 12032. The proportions shown are based on calculated mineral occurrences [84]. As shown, zirconolite and apatite dominate but account for $<0.5 \%$ total of the fragments' mineral assemblage.

Also shown in Figure 10 is the mineralogy associated with the granite lithic fragment (clast number: 12032,366-19) in which the authors [84] note as having a unique textural and mineralogical assemblage compared to other lunar lithologies. Similar to terrestrial granites, the major mineralogy of 12032,366-19 is characterized by alkali feldspar, quartz, and plagioclase feldspar and in their given relative proportions classify it as a true granite in quartz-alkali feldspar-plagioclase (QAP) space. With respect to the accessory mineralogy, this is characterized by zirconolite, apatite, and zircon. Collectively, REE-bearing phases only account for $<0.7 \%$ of the granite fragment and it should be noted that these characteristics are based on a modal recombination calculation based on the granite fragments mineralogy, mineral chemistry, and bulk rock signature. Using results from an image analysis only, the REE-bearing accessory phases constitute only "trace" amounts [84].

Lunar granites are one the rarest sample types throughout the returned Apollo sample collection and are rare throughout the lunar geological record. However, REE-bearing phases throughout the lunar sample collection (returned and meteoritic) are present as minor components in other lunar lithologies. These minerals include whitlockite, chevkinite/perrierite, and monazite in addition to apatite, merrillite, and zirconolite. Their REE-normalized signatures are shown in Figure 11, alongside lunar zircon as an example of a HREE-enriched lunar phase. 


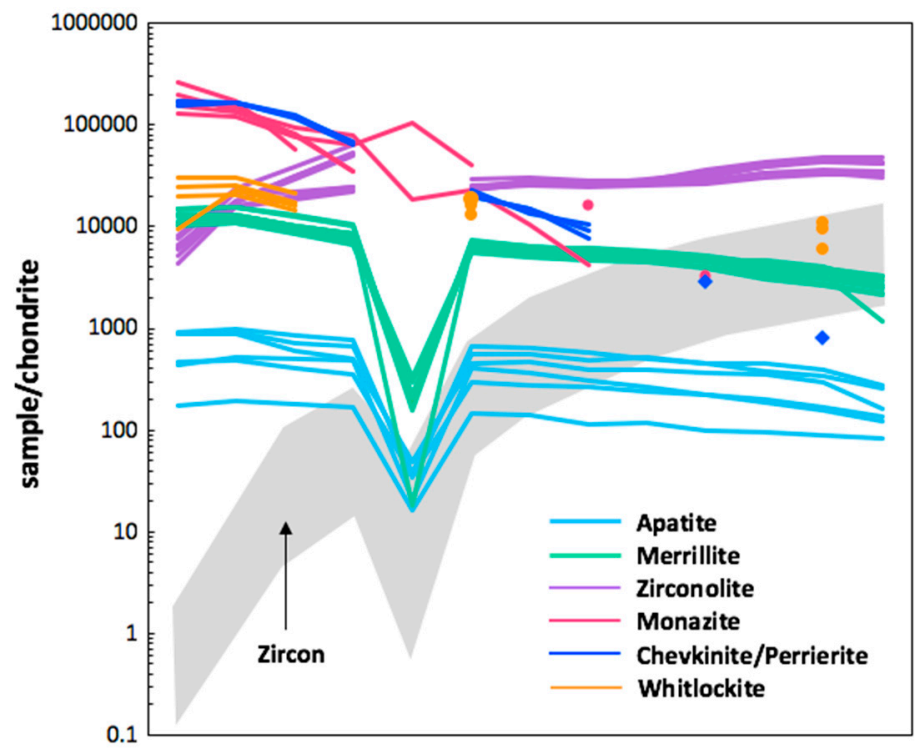

Figure 11. Chondrite normalized $\left(_{\mathrm{N}}\right)$ REE profiles for lunar apatite, merrillite, zirconolite, monazite, chevkinite-perrierite, whitlockite, and zircon [42,83,87-90]. The majority of the phases shown are relatively LREE-enriched with zirconolite (and zircon) the only phases exhibiting relative HREE enrichment.

With respect to REE abundance, members of the monazite, perrierite, and chevkinite groups exhibit the highest concentration of REEs with LREE signatures $>10^{5}$ times that of chondrite, and have steep overall REE patterns. Whitlockite and merrillite are both LREE-enriched but by an order of magnitude less than those of the above groups. Zirconolite (and zircon) are the only HREE-enriched lunar accessory phases, with zirconolite exhibiting HREE chondrite-normalized values $>10^{4}$ times that of chondrite and several orders of magnitude greater enrichment in the LREEs compared to zircon. In addition to the minerals shown in Figure 11, rarer REE-bearing phases have been reported in lunar lithologies. This includes minerals from the metamict Y-rich betafite group in Apollo sample 14321,1494 (a $\sim 1.8 \mathrm{~g}$ granite clast in sample 14321 [91]). These crystals contain $12.81 \mathrm{wt} \%$ REOs (including $\left.2.38 \mathrm{wt} \% \mathrm{Nd}_{2} \mathrm{O}_{3}\right)$ and $12 \mathrm{wt} \% \mathrm{Y}_{2} \mathrm{O}_{3}(94,500 \mathrm{ppm} \mathrm{Y})$ in addition to high concentrations of $\mathrm{U}$ $(38,200 \mathrm{ppm})$. This particular sample (14321) is referred to as Big Bertha, and is the third largest sample ever returned by an Apollo mission weighing in at $8998 \mathrm{~g}$. In addition to the above minerals, another REE-bearing phase present in this clast-rich breccia is whitlockite, reported in an alkali anorthosite clast $(14321,117)$. On a more historical note, this breccia also contains armalcolite, a Ti-rich oxide phase that was first found on the Moon in an Apollo 11 sample and named after astronauts Armstrong, Aldrin, and Collins.

Other, all be it rarer, REE-bearing lunar phases include tranquillityite and dysanalyte ( $\mathrm{Nb}$-rich perovskite). Tranquillityite $\left(\mathrm{Fe}_{8}\left(\mathrm{Y}, \mathrm{Zr}_{2} \mathrm{Ti}_{3} \mathrm{Si}_{3} \mathrm{O}_{24}\right.\right.$ [92] was a new mineral at its time of identification in Apollo 11 and 12 samples [93]. It is enriched in both $\mathrm{Nd}$ and $\mathrm{Y}$ (up to $0.25 \mathrm{wt} \%$ and $4 \mathrm{wt} \%$ respectively) and was not identified on Earth until 2012 [94] where it was reported in c. 1.07 Ga doleritic dikes and sills in the Pilbara Craton, Australia. As with lunar samples (e.g., Apollo basalt 78578), it is observed co-existing with baddeleyite. From three sections of Apollo 11 basalt sample 10047 (11, 227, and 230), the REE composition of co-existing lunar tranquillityite, baddeleyite, and zirconolite were reported [95]. In tranquillityite (1.85 wt \% REOs), the HREEs (and Ce) were the most abundant with chondrite-normalized patterns typically MREE-HREE enriched by $10^{3}-10^{4}$ over chondrite and absolute elemental concentrations >100,000 ppm, e.g., Ce: 50,029 ppm, Gd: 318,740 ppm, Er: 271,101 ppm, and $\mathrm{Yb}: 158,075 \mathrm{ppm}$. By comparison, co-existing baddeleyite was also HREE enriched with Gd at 60,731 ppm, Er at 69,962 ppm, and $\mathrm{Yb}$ at 35,128 ppm (at $90.49 \mathrm{wt} \% \mathrm{ZrO}_{2}$ ). Rarer still is "dysanalyte" [96]. This has been observed as being intricately intergrown with baddeleyite in Apollo 11 sample 10047,13 where total REE concentrations are reported at $\sim 10 \%$ [97]. A later study [98] also reported the 
occurrence of Zr-rich minerals $(<30 \mu \mathrm{m})$ in Apollo 14 and 15 samples, including the previously reported dysanalyte, but cautioned the use of the nomenclature with compositions shown to be closer to that of zirkelite or armalcolite [99].

Despite their rarity, the occurrence of Zr-REE-rich phases in lunar samples is fundamentally important to consider within the context of the petrogenesis of chemically evolved lithologies on the Moon. This is because they are concentrated in the evolved, felsic derivatives of parental mare and/or KREEP basalts (at least in part, see discussion later [98]). They contain higher concentrations of REOs than whitlockite (Figure 11), are notable carriers of heat-producing elements, and provide insights into the Moons so-called "granite problem" [98,100,101]. This "problem" originates from the observation of K-rich, rhyolitic glass present in the mesostasis areas of the lunar mare basalts that are associated with KREEP-like minerals, and the observation that crystalline granitic clasts are also a crucial component of the lunar crust at the Apollo 14 site [98,100]. In addition, the chemical signatures of the mare basalts at the Apollo 14 sites can be modelled via granite assimilation at depth, yet $<0.03 \%$ of returned Apollo samples $(n=22)$ are classified as granitic [71,101]. Lunar granites have the potential to be a fundamentally significant components of the lunar crustal stratigraphy at depth yet the role they have played in the chemical evolution of the Moon remains largely enigmatic. There are several chemical criteria that need to be met in any model in order to explain lunar granite petrogenesis. These are [73]: (1) LREE > MREE; (2) higher K/La and Ba/La signatures compared to mare basalts and KREEP components [101]; (3) higher $\mathrm{SiO}_{2}$ contents and $\mathrm{Mg}$ numbers $\left(\mathrm{Mg} \#=100 \times \mathrm{Mg} /\left(\mathrm{Mg}+\mathrm{Fe}^{2+}\right)\right)$ than mare basalts, and (4) lower concentrations of REEs than KREEP. One early model that was proposed, that would chemically account for the presence of a KREEP reservoir and the petrogenesis of lunar granites, was silicate-liquid immiscibility. In this scenario, two chemically distinct melts are segregated: a K-rich melt and a REEP-rich melt. This not only accounted for the degree of fractionation required from a primordial LMO (Figure 7) to produce a residual liquid that has the hypothesized urKREEP composition (Figure 9b) but also provided a source for lunar granite production through differentiation from the K-rich melt $[73,101]$. Alternatively, lunar granites were proposed to be the result of crystal fractionation [83]. Issues with these early models (considered exclusive for now) were associated with accounting for (1) the relatively high Mg\# of lunar granites (up to 64) through fractionation of a parental

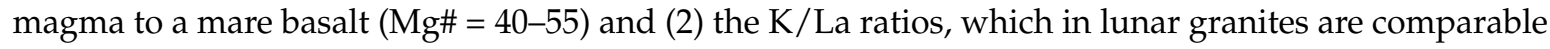
to $\operatorname{KREEP}(\mathrm{K} / \mathrm{La}=60-100)$ and which can be elevated through melt immiscibility, but not while simultaneously accounting for corresponding Fe contents $[73,101]$. One potential solution is a hybrid model $[73,102]$ whereby a component of silicate liquid immiscibility is considered during the later stages of crystal fractionation (the last 10\%) although there is no complete separation. It should be noted that early fractionation, particularly of plagioclase, apatite and zircon, is still fundamentally required in order to produce the observed REE patterns of lunar granites (Eu anomaly, concave-up shape, and HREE depletion respectively; Neal and Taylor, 1987). From more recent work [102], following the identification of a "pristine lunar granite" (sample 12032,366-19, see earlier), the petrogenesis of lunar granites was again associated with significant crystal fractionation and melt evolution, but was further tested by evaluating the extreme chemical differentiation of potential parental melts-KREEP (from basalt) and a basaltic-andesite (from glass) up to $98 \mathrm{~mol} \%$ and $95 \mathrm{~mol} \%$ respectively. Following these extreme degrees of fractionation, $\mathrm{SiO}_{2}$ contents were still not satisfied hence the role of a second process: density-driven separation of different phases, was invoked in order to account for lunar granite signatures, notably with the potential absence of any silicate liquid immiscibility [102]. A potential third model is briefly mentioned here and invokes the role of crustal melting. In this scenario, a heat source (e.g., from basaltic underplating) elevates preexisting lunar lithologies above their solidii in order to generate the silicic melts required to produce chemically evolved lunar compositions. This has been shown to be possible using terrestrial basalts but experimental data on comparable lunar lithologies is currently lacking. A recent study [103] explored this model employing lunar compositions with results in support of lunar crust partial melting in the generation of chemically evolved lunar melts with the following caveats: (1) partial melting at $\sim 1 \mathrm{~km}(0.005 \mathrm{GPa})$ depth in the lunar interior is 
comparable to experimental run products produced at atmospheric pressures in the absence of silicate liquid immiscibility and (2) slow cooling rates permit lunar gravity-driven separation of the partial melt generated at depth. Importantly however, is the implication that silicate liquid immiscibility is absent in the generation of lunar granites (and evolved lithologies). From this [103], the observed behavior of Th during partial melting (at $1 \mathrm{~km}$ depth) is consistent with higher compatibilities in Fe-rich melts compared to Si-rich melts. By inference, $20 \mathrm{ppm}$ Th in a lunar granite could therefore only be accounted for via silicate liquid immiscibility if there was a co-existing Fe- and Th-rich reservoir and presently, this has not been identified. It should be noted however that these results do not negate the role of silicate liquid immiscibility in the generation of chemically evolved melts in the Moon, but that higher pressures than those investigated to date are likely required [103].

The question associated with, and models of, extraterrestrial granite formation extends to other planetary bodies in the Solar System as well, including Mars and Venus. To date, granites on extraterrestrial bodies show trace element geochemical affinity to terrestrial A-type granites and formation as early as $30 \mathrm{My}$ after the formation of the Solar System [104,105]. The question therefore is not whether granite, a significant host of REE-deposits on Earth, exists on other planetary bodies but how much of it exists and if it is present in volumetrically significant amounts to form "stable continental nuclei" [105]. Within a lunar context, the Apollo 14 landing site has proved to host the most "pristine" granitic samples. This spatial association is worthy of note due to the proximity of the landing site to the geochemically distinct lunar Western Highland Province, a region with elevated $\mathrm{K}$, Th, and $\mathrm{U}$ as revealed by remote sensing [106]. This is one of four regions identified to date within the PKT that have UV absorption and mid-infrared characteristics consistent with the presence of evolved mineralogies (silica glass, quartz, \pm alkali feldspar $[105,106])$.

\section{Evaluating Earth's Moon as a Potential Future Resource}

For a deposit to be considered a resource, and economically mined as an ore, the presence of that targeted element or elements and their host mineral(s) must first be concentrated through one or more differentiation processes. These concentrations are typically higher than average crust [107]. Figure 12 compares the total REO (in wt \%) present in lunar lithologies, including lunar granites and the urKREEP reservoir, to several of Earth's most significant REE-related deposits (see also, Figure 2). As shown, no currently sampled lunar lithology can be considered a resource with even the urKREEP (and a high KREEP-bearing Apollo 16 sample) containing $<0.5 \mathrm{wt} \%$ REOs. This is in contrast to the REE deposit at Bayan Obo, currently the world's most significant producer of REEs estimated at $>4 \mathrm{wt} \%$ REOs. Not shown on Figure 12 is the REE deposit at Mt. Weld, Australia where $9.7 \mathrm{wt} \%$ of REOs is estimated.

While the summarized data in Figure 12 does not convey an optimistic view for lunar REE resources, it has been comprehensively documented that samples returned to date (including meteorites) from the Moon contain REE-bearing phases, and that they have the potential to be associated with the petrogenesis of chemically evolved lunar melts (see earlier). From present day observations of the abundance of heat-producing elements in the PKT (Figure 9a) and the associated high-Th regions on the lunar nearside, the volume of KREEP-rich lithologies beneath the region has been estimated at $2.2 \times 10^{8} \mathrm{~km}^{3}$ [108]. This corresponds to a potential, REE resource of $\sim 2.25 \times 10^{14} \mathrm{~kg}-4.5 \times 10^{14} \mathrm{~kg}$ [109] which is by no means insignificant. In addition, the chemically evolved high silica areas identified on the lunar surface to date are also consistent with elevated Th and low Fe regions, and are chemically distinct from surrounding feldspathic regions [105]. These observations have only been made possible due to the significant advancement in the technology employed during remote sensing investigations of planetary crusts [106]. Using Earth as an analog, it is observed that A-type granites are hosts to significant ore-related deposits including those rich in $\mathrm{Nb}-\mathrm{Ta}$, REE, and U-Th. While to date within this context, only regions of $U$ and Th enrichment have been detected (e.g., Figure 9a), it is worth proposing that future exploration of the lunar surface may yet reveal U-Th-REE regions associated with the distribution of chemically evolved lithologies. 
In order for this to manifest, the technology needed for extraction would first need to be tested and validated and there are several logistical challenges associated with mining on the Moon.

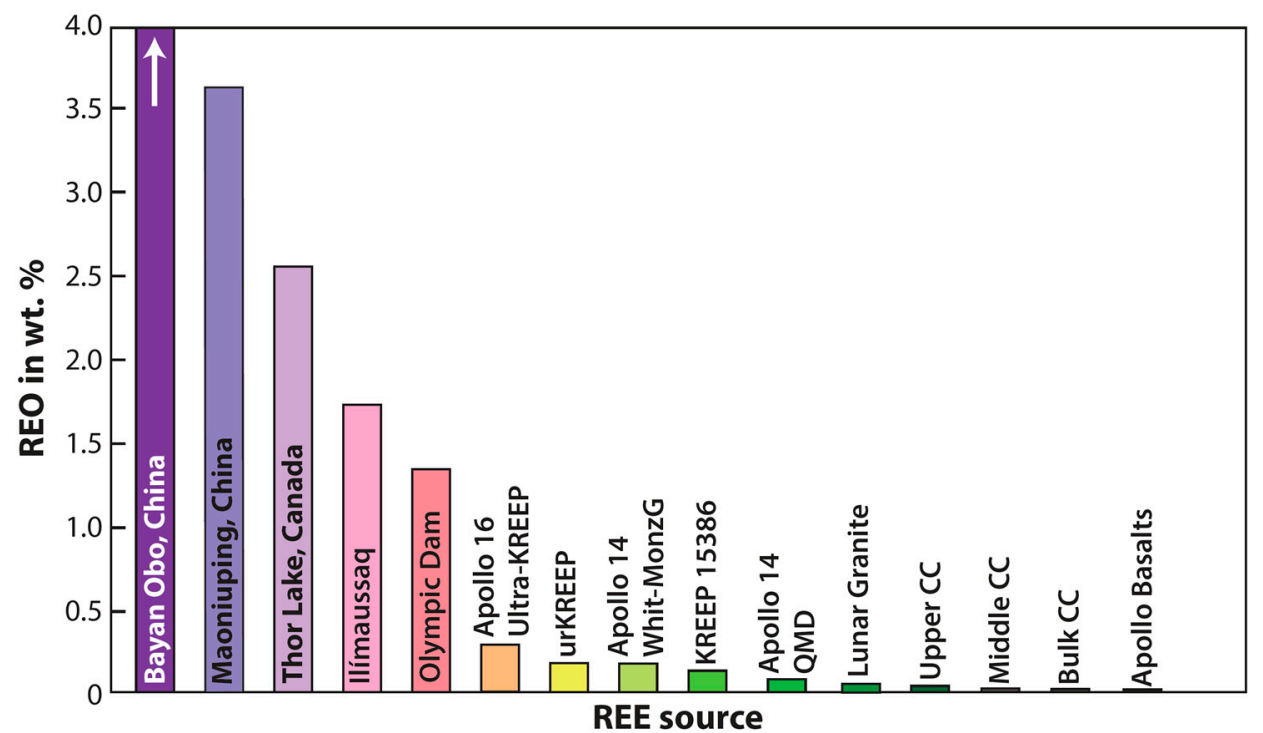

Figure 12. Bulk REE signatures in lunar lithologies compared to bulk values for Earth's upper (UCC), middle (MCC), lower (LCC), and bulk (BCC) continental crust. As shown, the profiles of the FAN and KREEP components complement each other with characteristic positive and negative Eu-anomalies respectively.

Transporting shipments of materials to the Moon from Earth would cost $>\$ 20,000 \mathrm{USD} / \mathrm{kg}$ hence exploitation of lunar resources would be economically beneficial if materials could be obtained in situ [110]. Conducting mining operations on the Moon like those on Earth, poses a significant technological challenge. The following presents issues which would need to be overcome [111]: (1) energy intensive approaches; (2) labor (automation will be critical to the success of mining operations on the Moon); (3) heavy terrestrial equipment; and (4) the lunar environment contains glass-rich dust (see below), is a vacuum, experiences temperature fluctuations between $-170{ }^{\circ} \mathrm{C}$ (night) and $125{ }^{\circ} \mathrm{C}$ (day), has a low gravity of $1.6 \mathrm{~m} / \mathrm{s}^{2}$ (compared to Earth's $9.81 \mathrm{~m} / \mathrm{s}^{2}$ ), and is exposed to radiation from incoming cosmic rays and solar flares. In addition, the lunar surface is impacted by micrometeoroids [112]. For an area of $\sim 150 \mathrm{~m}^{2}$, one micrometeoroid $>0.5 \mathrm{~mm}$ diameter hits per year with an impacting velocity of $13 \mathrm{~km} / \mathrm{s}$. In models, this excavates a crater $\sim 1.8 \mathrm{~mm}$ in diameter and a depth $>1 \mathrm{~mm}$. While the risk to lunar structures, base supports, processing facilities, or instrumentation is difficult to assess and quantify, the hazard exists [112].

For the foreseeable future tele-operated robots will likely be the "primary source of labor on the Moon" and would be used for scientific exploration, but also in the construction of the first Moon base [110]. The initial exploitation and mining of the Moons resources would be carried out by equipment transported from Earth yet the extreme temperature fluctuations would subject machinery to significant thermal stress. In addition, dust is abundant and is electrostatically charged so it would adhere to equipment, spacesuits, and interfere with seals around air locks. Lunar dust is understood to have been responsible for the hay-fever like symptoms Apollo 17 astronaut Harrison "Jack" Schmitt experienced (the only geologist to ever land on the Moon as part of the Apollo program), who described feeling congested while in the Lunar Module following a moonwalk around Taurus-Littrow valley. Radical design changes of operational mining equipment would therefore be needed before they could be used to viably extract resources from the lunar regolith [111].

Our understanding of the geological and lithologically diversity on Moon will only be enhanced by targeted missions to regions of the lunar surface that remain unsampled by sample return missions. An alternative approach would be to carry out in situ measurements via robots capable of acquiring 
major, minor, and trace element data, in addition to isotopic data (Farside Explorer and LunarNet proposals $[56,113,114])$. Within the context of renewed excitement and enthusiasm for the Moon as a potential extraterrestrial resource however comes the question of sustainability and associated policy. Current lunar regulation "is based on cold war treaties", hence new agreements on sustainability would need to be considered as a "means of ensuring cooperation on sustainable lunar development" [115].

Ultimately, consideration of both terrestrial and extraterrestrial non-traditional, potentially economically viable, REE deposits is likely going to be needed in order to sustain the 5-10\% growth/year in the demand of these resources, even in the presence of recycling $[87,101,116]$. As technology advances, and our ability to detect and quantify the presence of potential resources, increases, it is with hope that new deposits will be identified. With that, our understanding of planetary differentiation and associated chemical evolution will improve, likely providing more questions than answers. Hence science as well as society stands to benefit.

\section{Conclusions}

On Earth, REEs constitute $<0.022 \%$ of the elemental budget of Earth's upper crust but are intricately associated with specific geological environments. Of the 799 REE deposits worldwide (including potential resources) for which REE-mineralogical data is currently available for, 122 are associated with evolved and/or alkaline igneous activity (not including carbonatites, of which there are 149). Within these deposits, the most common occurring mineral groups are monazite, eudialyte, bastnäsite, and allanite all of which are LREE enriched to variable degrees. These resources are however, non-renewable and not unlimited hence if the annual 5-10\% growth in demand for REEs is to be sustained, exploration of alternative resources needs to be considered. One potentially viable option is the Earth's Moon, out nearest neighbor in space and a planetary body that similarly underwent silicate-metal differentiation early during its evolution (c. $4.45 \mathrm{Ga}$ ).

The Earth's Moon underwent differentiation to form a crust, mantle, and core during its early planetary evolution. Following $\sim 99 \%$ crystallization from its initially molten state, the remaining liquid was enriched in elements which were geochemically incompatible in the major lunar rock forming minerals (olivine, anorthitic feldspar, and pyroxene). This late-stage component, termed KREEP (potassium-REE-phosphorus), is hypothesized to exist as a geochemical reservoir at depth within the lunar interior and to date has been identified in major lunar lithologies (including lunar granites) through its distinct chemical signature. In addition, on the lunar nearside, the Procellarum KREEP Terrane (PKT) potentially contains up to $4.5 \times 10^{14} \mathrm{~kg}$ of REEs at depth. At present however, based on returned samples (including meteorites), REE-bearing minerals are found only as accessory phases within lunar lithologies and only 22 samples have been classified as granites to date. The major REE-bearing lunar minerals include members of the apatite and monazite groups. REE-bearing minerals similar to those found on Earth are present on the Moon such as baddeleyite and minerals of the apatite, monazite, perovskite, betafite, and chevkinite/perrierite groups. Although, other carriers of REEs on the Moon, such as tranquillityite and merrillite are rarer on Earth. Within the context of their occurrence and distribution though, they do not (based on current understanding) exist as viable economic deposits.

Regarding the production of chemically evolved lithologies on the Moon, areas high in silica correlate with regions of higher $\mathrm{U}$ and Th (e.g., the PKT) as determined by remote sensing missions and are geochemically distinct from feldspathic rich areas. From a terrestrial analog, these general characteristics are consistent with A-type granites where enrichment in U-Th (and REE, $\mathrm{Nb}-\mathrm{Ta}$ ) is also observed hence investigation and characterization of high- silica, high U-Th regions on the Moon is proposed here as a target for future REE resource exploration of the Moon. However, with future exploration on the Moon comes logistical challenges. Shipment of materials back to Earth is expensive (current estimate at $>\$ 20,000 \mathrm{USD} / \mathrm{kg}$ ) and any in situ utilization would have to overcome the hostile lunar environment: dust, changes in temperatures of $\sim 295^{\circ} \mathrm{C}$ between day and night, incoming solar radiation, and the micrometeorite flux for example. 
As technology advances and our understanding of our own planet and its neighbors progresses, it is with hope that new and non-traditional REE resources are identified. With continued exploration of our nearest neighbor in space comes the opportunity to not only identify and quantify new potential REE resources, but to advance our understanding of early planetary differentiation and the processes and timescales associated with the formation of geochemical reservoirs on other Solar System bodies. Therefore, an opportunity for our scientific comprehension of planet-forming processes to advance also exists.

Supplementary Materials: The following are available online at http://www.mdpi.com/2075-163X/8/10/455/s1.

Author Contributions: C.L.M. designed the overall structure of the manuscript and wrote $90 \%$ of this article. Both C.L.M. and B.J.S. compiled the literature data, including the geochemical data, from terrestrial and extraterrestrial sources.

Funding: This research received no external funding.

Acknowledgments: We thank Guest Editor Joan Carles Melgarejo Draper for the opportunity to contribute to this special issue of Minerals: Mineral Deposits of Critical Elements. We thank two anonymous reviewers for their insightful and constructive comments on earlier drafts of this manuscript.

Conflicts of Interest: The authors declare no conflicts of interest.

\section{References}

1. Bottrell, S.H.; Yardley, B.W.D. The composition of a primary granite-derived ore fluid from S. W. England, determined by fluid inclusion analysis. Geochem. Cosmochim. Acta 1998, 52, 585-588. [CrossRef]

2. Heinrich, C.A. The chemistry of hydrothermal tin(-tungsten) ore deposition. Econ. Geol. 1990, 85, 457-481. [CrossRef]

3. Pirajno, F. Hydrothermal Mineral Deposits; Springer: Berlin/Heidelberg, Germany, 1992; 709p.

4. Braun, J.-J.; Pagel, M.; Herbilln, A.; Rosin, C. Mobilization and redistribution of REEs and thorium in a syenitic lateritic profile: A mass balance study. Geochem. Cosmochim. Acta 1993, 57, 4419-4434. [CrossRef]

5. Candela, P.A. A Review of Shallow, Ore-related Granites: Textures, Volatiles, and Ore Metals. J. Petrol. 1997, 38, 1619-1633. [CrossRef]

6. Haapala, I. Magmatic and Postmagmatic Processes in the Tin-mineralized Granites: Topaz-bearing Leucogranite in the Eurajoki Rapakivi Granite Stock, Finland. J. Petrol. 1997, 38, 1645-1659. [CrossRef]

7. Zaitsev, A.N.; Wall, F; Le Bas, M.J. REE-Sr-Ba minerals from the Khibina carbonatites, Kola Peninsula, Russia: Their mineralogy, paragenesis and evolution. Miner. Mag. 1998, 62, 225-250. [CrossRef]

8. Mitchell, R.H. Carbonatites and carbonatites and carbonatites. Can. Miner. 2005, 43, 2049-2068. [CrossRef]

9. Sial, A.N.; Bettencourt, J.S.; De Campos, C.P.; Ferreira, V.P. Granite-related ore deposits: An introduction. J. Geol. Soc. Spec. Publ. 2011, 350, 1-5. [CrossRef]

10. Feng, C.; Zhao, Z.; Qu, W.; Zeng, Z. Temporal consistency between granite evolution and tungsten mineralization in the Huamei'ao, southern Jiangxi Province, China: Evidence from precise zircon U-Pb, molybdenite Re-Os, and muscovite ${ }^{40} \mathrm{Ar}^{-39} \mathrm{Ar}$ isotope geochronology. Ore Geol. Rev. 2015, 65, 1005-1020. [CrossRef]

11. Dostal, J. Rare Earth Element Deposits of Alkaline Igneous Rocks. Resources 2017, 6, 34. [CrossRef]

12. Gardiner, N.J.; Hawkesworth, C.J.; Robb, L.J.; Whitehouse, M.J.; Roberts, N.M.W.; Kirkland, C.L.; Evans, N.J. Contrasting Granite Metallogeny through the Zircon Record: A Case Study from Myanmarr. Nat. Sci. Rep. 2017, 7, 1-9. [CrossRef] [PubMed]

13. Simons, B.; Andersen, J.C.Ø.; Shail, R.K.; Jenner, F.E. Fractionation of Li, Be, Ga, Nb, Ta, In, Sn, Sb, W and Bi in the peraluminous Early Permian Variscan granites of the Cornubian Batholith: Precursor processes to magmatic-hydrothermal mineralization. Lithos 2017, 278-281, 491-512. [CrossRef]

14. Xiao, B.; Li, Q.; He, S.; Chen, X.; Liu, S.; Wang, Z.; Xu, X.; Chen, J. Contrasting geochemical signatures between Upper Triassic Mo-hosting and barren granitoids in the central segment of South Qinling orogenic belt, central China: Implications for Mo exploration. Ore. Geol. Rev. 2017, 81, 518-534. [CrossRef]

15. Massari, S.; Ruberti, M. Rare earth elements as critical raw materials: Focus on international markets and future strategies. Resour. Policy 2013, 38, 36-43. [CrossRef] 
16. Goodenough, K.M.; Wall, F.; Merriman, D. The Rare Earth Elements: Demand, Global Resources, and Challenges for Resourcing Future Generations. Nat. Resour. Res. 2017, 27, 201-216. [CrossRef]

17. Golev, A.; Scott, M.; Erskine, P.D.; Ali, S.H.; Ballantyne, G.R. Rare earth element supply chains: Current status, constraints and opportunities. Resour. Policy 2014, 41, 52-59. [CrossRef]

18. Haque, N.; Hughes, A.; Lim, S.; Vernon, C. Rare earth elements: Overview of mining, mineralogy, uses, sustainability and environmental impact. Resources 2014, 3, 614-635. [CrossRef]

19. McLeod, C.L.; Krekeler, M.P.S. Sources of Extraterrestrial Rare Earth Elements: To the Moon and Beyond. Resources 2017, 6, 40. [CrossRef]

20. Zhou, B.; Li, Z.; Chen, C. Global Potential of Rare Earth Resources and Rare Earth Demand from Clean Technologies. Minerals 2017, 7, 203. [CrossRef]

21. United States Geological Survey (USGS). Mineral Commodity Summaries 2017. 2018. Available online: https:/ / minerals.usgs.gov/minerals/pubs/mcs/2018/mcs2018.pdf (accessed on 5 May 2018).

22. Chen, W.; Honghui, H.; Bai, T.; Jiang, S. Geochemistry of Monazite within Carbonatite Related REE Deposits. Resources 2017, 6, 51. [CrossRef]

23. Rudnick, R.L.; Gao, S. Composition of the Continental Crust. Treatise Geochem. 2003, 3, 1-64.

24. Paikowsky, D.; Tzezana, R. The politics of space mining-An account of a simulation game. Acta Astronaut. 2018, 142, 10-17. [CrossRef]

25. Verplanck, P.L.; Van Gosen, B.S. Carbonatite and Alkaline Intrusion-Related Rare Earth Element Deposits-A Deposit Model. USGS Open-File Report 2011-1256. Available online: https://pubs.usgs. gov/of/2011/1256/report/OF11-1256.pdf (accessed on 7 May 2018).

26. Fitton, J.G.; Upton, B.G.J. Alkaline Igneous Rocks; Geological Society Special Publication; Blackwell Scientific: Hoboken, NJ, USA, 1987; Book 30; 568p.

27. Sørensen, H. The Alkaline Rocks; Wiley: Hoboken, NJ, USA, 1974; 622p.

28. United States Geological Survey (USGS). Rare Earth Element Mines, Deposits, and Occurrences. 2002. Available online: https:/ / mrdata.usgs.gov/ree/ (accessed on 5 May 2018).

29. Kretz, R. Symbols for rock-forming minerals. Am. Mineral. 1983, 68, 277-279.

30. Whitney, D.L.; Evans, B.W. Abbreviations for names of rock-forming minerals. Am. Mineral. 2010, 95, $185-187$. [CrossRef]

31. Hudson Institute of Mineralogy-Mindat. Available online: https://www.mindat.org/ (accessed on 2 October 2018).

32. Mineralogy Database. Available online: www.webmineral.com (accessed on 2 October 2018).

33. Friis, H.; Balić-Žunić, T.; Williams, C.T.; Garcia-Sanchez, R. Incorporation of REE into leucophanite: A compositional and structural study. Mineral. Mag. 2007, 71, 625-640. [CrossRef]

34. Macdonald, R.; Saunders, M. Chemical variation in minerals of the astrophyllite group. Mineral. Mag. 1973, 39, 97-111. [CrossRef]

35. Bühn, B.; Rankin, A.H.; Radtke, M.; Haller, M.; Knöchel, A. Burbankite, a (Sr,REE,Na,Ca)-carbonate in fluid inclusions from carbonatite-derived fluids: Identification and characterization using Laser Raman spectroscopy, SEM-EDX, and synchrotron micro-XRF analysis. Am. Mineral. 1999, 84, 1117-1125. [CrossRef]

36. Mariano, A.N.; Roeder, P.L. Wöhlerite: Chemical Composition, Cathodoluminescence and Environment of Crystallization. Can. Mineral. 1989, 27, 709-720.

37. Rubatto, D.; Hermann, J.; Buick, I. Temperature and Bulk Composition Control on the Growth of Monazite and Zircon During Low-pressure Anatexis (Mount Stafford, Central Australia). J. Petrol. 2006, 47, 1973-1996. [CrossRef]

38. Castor, S.B. Rare Earth Deposits of North America. Resour. Geol. 2008, 58, 337-347. [CrossRef]

39. Pfaff, K.; Krumrei, M.A.W.; Marks, T.; Wenzel, T.; Rudolf, T.; Markl, G. Chemical and physical evolution of the "lower layered sequence" from the nepheline syenitic Ilímaussaq intrusion, South Greenland: Implication for the origin of magmatic layering in peralkline felsic liquids. Lithos 2008, 106, 280-296. [CrossRef]

40. Graupner, T.; Mühlbach, C.; Schwarz-Schampera, U.; Henjes-Kunst, F.; Melcher, F.; Terblanche, H. Mineralogy of high-field strength elements (Y, Nb, REE) in the world-class Vergenoeg fluorite deposit, South Africa. Ore. Geol. Rev. 2015, 64, 583-601. [CrossRef]

41. Guo, H.; Xiao, Y.; Xu, L.; Sun, H.; Huang, J.; Hou, Z. Origin of allanite in gneiss and granite in the Dabie orogenic belt, Central East China. J. Asian Earth. Sci. 2017, 135, 243-256. [CrossRef] 
42. Sun, S.S.; McDonough, W.F. Chemical and isotopic systematics of oceanic basalts: Implications for mantle composition and processes. Geol. Soc. Lond. Spec. Pub. 1989, 42, 313-345. [CrossRef]

43. Sokolova, E.; Hawthorne, F.C.; Della Ventura, G.; Kartashov, P.M. Chevkinite-(Ce): Crystal structure and the effect of moderate radiation-induced damage on the site-occupancy refinement. Can. Mineral. 2004, 42, 1013-1025. [CrossRef]

44. Konopleva, N.G.; Yu, G.; Ivanyuk, Y.A.; Pakhomovsky, V.N.; Yakovenchuk, Y.; Mikhailova, A. Loparite-(De) from the Khibiny Alkaline Pluton, Kola Peninsula, Russia. Geol. Ore Depos. 2017, 59, 729-737. [CrossRef]

45. Förster, H.-J. The chemical composition of REE-Y-Th-U-rich accessory minerals in peraluminous granites of the Erzgebirge-Fichtelgebirge region, Germany. Part II: Xenotime. Am. Mineral. 1998, 83, 1302-1315. [CrossRef]

46. Sokolova, E.; Hawthorne, F.C. From structure topology to chemical composition, XIV. Titanium silicates: Refinement of the crystal structure and revision of the chemical formula of mosandrite, a Group-1 mineral from the Saga mine, Morje, Porsgrunn, Norway. Mineral. Mag. 2013, 227, 594-603.

47. Yang, Z.; Smith, M.; Henderson, P.; Lebas, M.J.; Tao, K.; Zhang, P. Compositional variation of aeschynite-group minerals in the Bayan Obo Nb-REE-Fe ore deposit, Inner Mongolia, China. Eur. J. Mineral. 2001, 13, 1207-1214. [CrossRef]

48. Škoda, R.; Plasil, J.; Jonsson, E.; Čopjakova, R.; Langhof, J.; Galiova, M.V. Redefinition of thalenite-(Y) and discreditation of fluorthalenite-(Y): A re-investigation of type material from the Österby pegmatite, Dalarna, Sweden, and from additional localities. Mineral. Mag. 2015, 79, 965-983. [CrossRef]

49. Jordens, A.; Cheng, Y.P.; Waters, K. A Review of the Benefication of Rare Earth Element Bearing Minerals. Mineral. Eng. 2013, 41, 97-114. [CrossRef]

50. Long, K.R.; Van Gosen, B.S.; Foley, N.K.; Cordier, D. The Principal Rare Earth Elements Deposits of the United States-A Summary of Domestic Deposits and a Global Perspective; U.S.G.S. Scientific Investigations Report; U.S. Department of the Interior, U.S. Geological Survey: Reston, VA, USA, 2010; 96p.

51. BGS (British Geological Survey). Rare Earth Elements. 2011. Available online: https://www.bgs.ac.uk/ downloads / start.cfm?id=1638 (accessed on 8 June 2018).

52. Chehreh, C.S.; Rudolph, M.; Leistner, T.; Gutzmer, J.; Peujer, U.A. A review of rare earth minerals flotation: Monazite and Xenotime. Int. J. Min. Sci. Technol. 2015, 35, 877-883.

53. Geological Survey of Queensland (GSQ). Heavy Rare Earth elements (HREE) Opportunities in Queensland 2014. Available online: https://www.dnrm.qld.gov.au/_data/assets/pdf_file/0018/238104/hree.pdf (accessed on 8 June 2018).

54. Remeur, C. Rare Earth Elements and Recycling Possibilities. Library of the European Parliament. 2 May 2013. Available online: http:/ / www.europarl.europa.eu/RegData/bibliotheque/briefing/2013/130514/LDM_ BRI(2013)130514_REV1_EN.pdf (accessed on 21 June 2018).

55. Binnemans, K.; Jones, P.T.; Blanpain, B.; Gerven, T.V.; Yang, Y.; Walton, A.; Bucherts, M. Recycling of rare earths: A critical review. J. Clean. Prod. 2013, 51, 1-22. [CrossRef]

56. Crawford, I.A.; Anand, M.; Cockell, C.S.; Falcke, H.; Green, D.A.; Jaumann, R.; Wieczorek, M.A. Back to the Moon: The scientific rationale for resuming lunar surface exclamation. Planet. Space Sci. 2012, 74, 3-14. [CrossRef]

57. Wieczorek, M.A.; Jolliff, B.A.; Khan, A.; Pritchard, M.E.; Weiss, B.P.; Williams, J.G.; Hood, L.L.; Righter, K.; Neal, C.R.; Shearer, C.K.; et al. The constitution and structure of the lunar interior. Rev. Mineral. Geochem. 2006, 60, 221-264. [CrossRef]

58. Touboul, M.; Kleibe, T.; Bourdon, B.; Palme, H.; Wieler, R. Later formation and prolonged differentiation of the Moon inferred from W isotopes in lunar metals. Nature 2007, 450, 1206-1209. [CrossRef] [PubMed]

59. Jacobsen, S.A.; Morbidelli, A.; Rayond, S.N.; O’Brien, D.P.; Walsh, K.J.; Rubie, D.C. Highly siderophile elements in Earth's mantle as a clock for the Moon-forming impact. Nature 2014, 508, 84-87. [CrossRef] [PubMed]

60. Bottke, W.F.; Vokrouhlicky, S.; Marchi, S.; Swindle, T.; Scott, E.R.D.; Weirich, J.R.; Levison, H. Dating the Moon-forming giant impact with asteroidal meteorites. Science 2014, 348, 321-324. [CrossRef] [PubMed]

61. Barboni, M.; Boehnke, P.; Keller, B.; Kohl, I.E.; Schoene, B.; Young, E.D.; McKeegan, K.D. Early formation of the Moon 4.51 billion years ago. Sci. Adv. 2017, 3, e1602365. [CrossRef] [PubMed]

62. Taylor, S.R. Chemical evidence for lunar melting and differentiation. Nature 1973, 245, 203-205. [CrossRef] 
63. Taylor, S.R.; Jakes, P. The geochemical evolution of the moon. In Proceedings of the 5th Lunar Science Conference, Houston, TX, USA, 18-22 March 1974; pp. 1287-1305.

64. McLeod, C.L.; Brandon, A.D.; Fernandes, V.A.; Peslier, A.H.; Fritz, J.; Lapen, T.; Shafer, J.T.; Butcher, A.R.; Irving, A.J. Constraints on formation and evolution of the lunar crust from feldspathic granulitic breccias NWA 3163 and 4881. Geochemi. Cosmochim. Acta 2016, 187, 350-374. [CrossRef]

65. Prado, M. The Apollo and Luna Samples. 2002. Available online: http://www.permanent.com/l-apollo.htm (accessed on 28 May 2018).

66. Jolliff, B.L.; Gillis, J.J.; Haskin, L.A.; Korotev, R.L.; Wieczorek, M.A. Major lunar crustal terranes: Surface expressions and crust-mantle origins. J. Geophys. Res. Planets 2002, 105, 4197-4216. [CrossRef]

67. Taylor, G.J. Ancient lunar crust: Origin, composition, and implications. Elements 2009, 5, 17-22. [CrossRef]

68. Warren, P.H.; Wasson, J.T. The Origin of KREEP. Rev. Geophys. 1978, 17, 73-88. [CrossRef]

69. Shearer, C.K.; Elardo, S.M.; Petro, N.E.; McCubbin, F.M. Origin of the lunar highlands Mg-suite: An integrated petrology and geochemistry, chronology, and remote sensing perspective. Am. Mineral. 2015, 100, $294-325$. [CrossRef]

70. Snyder, G.A.; Taylor, A.L.; Halliday, A.N. Chronology and petrogenesis of the lunar highlands alkali suite: Cumulates from KREEP basalt crystallization. Geochim. Cosmochim. Acta 1995, 59, 1185-1203. [CrossRef]

71. Seddio, S.M.; Korotev, R.L.; Jolliff, B.L.; Wang, A. Silica polymorphs in lunar granite: Implications for granite petrogenesis on the Moon. Am. Mineral. 2015, 100, 1533-1543. [CrossRef]

72. Neal, C.R.; Taylor, L.A. Definition of Pristine, Unadulterated urKREEP Composition Using the "K-FRAC/REEP-FRAC" Hypothesis. In Proceedings of the 19th Lunar and Planetary Science Conference, Houston, TX, USA, 13-17 March 1989; pp. 772-773.

73. Neal, C.L.; Taylor, L.A. Metasomatic products of the lunar magma ocean: The role of KREEP dissemination. Geochem. Cosmochim. Acta 1989, 53, 529-541. [CrossRef]

74. Korotev, R.L.; Jolliff, B.L.; Zeigler, R.A.; Gillis, J.J.; Haskin, L.A. Feldspathic lunar meteorites and their implications for compositional remote sensing of the lunar surface and the composition of the lunar crust. Geochem. Cosmochim. Acta 2003, 67, 4895-4923. [CrossRef]

75. Korotev, R.L. Lunar geochemistry as told by lunar meteorites. Chem. Erde Geochem. 2005, 65, $297-346$. [CrossRef]

76. Rutherford, M.J.; Hess, P.C.; Ryerson, F.J.; Campbell, H.W.; Dick, P.A. The chemistry, origin, and petrogenetic implications of lunar granite and monzonite. In Proceedings of the 7th Lunar Science Conference, Houston, TX, USA, 15-19 March 1976; pp. 1723-1740.

77. Head, J.W.; McCord, T.B. Imbrian-age highland volcanism on the Moon; the Gruithuisen and Mairan domes. Science 1978, 199, 1433-1436. [CrossRef] [PubMed]

78. Hawke, B.R.; Lawrence, D.J.; Blewett, D.T.; Lucey, P.G.; Smith, G.A.; Spudis, P.D.; Taylor, G.J. Hansteen Alpha: A volcanic construct in the lunar highlands. J. Geophys. Res. 2003, 108, 5069. [CrossRef]

79. Ivanov, M.A.; Head, J.W.; Bystrov, A. The lunar Gruithuisen silicic extrusive domes: Topographic configuration, morphology, ages, and internal structure. Icarus 2016, 273, 262-283. [CrossRef]

80. Warren, P.H.; Taylor, G.J.; Keil, K.; Shirley, D.N.; Wasson, J.T. Petrology and chemistry of two large granite clasts from the Moon. Earth. Planet. Sci. Lett. 1983, 64, 175-185. [CrossRef]

81. Shih, C.-Y.; Nyquist, L.E.; Bogard, D.D.; Wooden, J.L.; Bansal, B.M.; Wiesmann, H. Chronology and petrogenesis of a $1.8 \mathrm{~g}$ lunar granite clast: 14321,1062. Geochem. Cosmochim. Acta 1985, 49, 411-426. [CrossRef]

82. Shih, C.-Y.; Nyquist, L.E.; Wiesmann, H. K-Ca chronology of lunar granites. Geochem. Cosmochim. Acta 1993, 57, 4827-4841. [CrossRef]

83. Korotev, R.L.; Jolliff, B.L.; Zeigler, R.A.; Seddio, S.M.; Haskin, L.A. Apollo 12 revisited. Geochem. Cosmochim. Acta 2011, 75, 1540-1573. [CrossRef]

84. Seddio, S.M.; Jolliff, B.L.; Korotev, R.L.; Zeigler, R.A. Petrology and geochemistry of lunar granite 12032,366-319 and implications for lunar granite petrogenesis. Am. Mineral. 2013, 98, 1697-1713. [CrossRef]

85. Ryder, G. Lunar sample 15405: Remnant of a KREEP basalt-granite differentiated pluton. Earth. Planet. Sci. Lett. 1976, 29, 255-268. [CrossRef]

86. McGee, P.E.; Warner, J.L.; Simonds, C.E.; Phinney, W.C. Introduction to the Apollo Collections. Part II: Lunar Breccias; Lyndon B. Johnson Space Center: Houston, TX, USA, 1979. 
87. Jolliff, B.L.; Hughes, J.M.; Freeman, J.J.; Zeigler, R.A. Crystal chemistry of lunar merrillite and comparison to other meteoritic and planetary suites of whitlockite and merrillite. Am. Mineral. 2006, 91, 1583-1595. [CrossRef]

88. Muhling, J.R.; Suvorova, A.A.; Rasmussen, B. The occurrence and composition of chevkinite-(Ce) and perrierite-(Ce) in tholeiitic intrusive rocks and lunar mare basalt. Am. Mineral. 2014, 99, 1911-1921. [CrossRef]

89. Wopenka, B.; Jolliff, B.L.; Zinner, E.; Kremser, D.T. Trace element zoning and incipient metamictization in a lunar zircon: Application of three microprobe techniques. Am. Mineral. 1996, 81, 902-912. [CrossRef]

90. Kartashov, P.M.; Bogatikov, O.A.; Mokhov, A.V.; Gorshkov, A.I.; Ashikhmina, N.A.; Magazina, L.O.; Koporulina, E.V. Lunar Monazites. Dokl. Earth Sci. 2006, 407A, 498-502. [CrossRef]

91. Meyer, C.; Yang, S.V. Tungsten-bearing yttrobetafite in lunar granophyre. Am. Mineral. 1988, 73, 1420-1425.

92. Heiken, G.H.; Vaniman, D.T.; French, B.M. Lunar Sourebook a User's Guide to the Moon; The Lunar Planetary Institute, Cambridge University Press: Cambridge, UK, 1991; 736p.

93. Lovering, J.F.; Wark, D.A.; Reid, A.F.; Ware, N.G.; Keil, K.; Prinz, M.; Bunch, T.E.; El Goresy, A.; Ramdohr, P.; Brown, G.M.; et al. Tranquillityite: A new silicate mineral from Apollo 11 and Apollo 12 basaltic rocks: Proceedings of the 2nd Lunar Science Conference. Geochem. Cosmochim. Acta 1971, 1 (Suppl. 2), $39-45$.

94. Rasmussen, B.; Fletcher, I.R.; Gregory, C.J.; Muhling, J.R.; Suvorova, A.A. Tranquillityite: The last lunar mineral comes down to Earth. Geology 2012, 40, 83-86. [CrossRef]

95. Rasmussen, B.; Fletcher, I.R.; Muhling, J.R. Pb/Pb geochronology, petrography and chemistry of Zr-rich accessory minerals (zirconolite, tranquillityite and baddeleyite) in mare basalt 10047. Geochem. Cosmochim. Acta 2008, 72, 5799-5818. [CrossRef]

96. Badescu, V. Moon: Prospective Energy and Material Resources; Springer: New York, NY, USA, 2012; 771p.

97. Ramdohr, R.; Goresey, A.E. Opaque minerals of the lunar rocks and dust from mare tranquillitatis. Science 1970, 167, 615-618. [CrossRef] [PubMed]

98. Brown, G.M.; Emeleus, C.H.; Holland, J.G.; Peckett, A.; Phillips, R. Mineral-chemical variations in Apollo 14 and Apollo 15 basalts and granitic fractions. Proc. Lunar Sci. Conf. 1972, 3, 141-157.

99. Busche, F.D.; Prinz, M.; Keil, K.; Bunch, T.E. Spinels and the petrogenesis of some Apollo 12 igneous rocks. Am. Mineral. 1972, 57, 1729-1747.

100. Brown, G.M.; Emeleus, C.H.; Holland, J.G.; Peckett, A.; Phillips, R. Picrite basalts, ferrobasalts, feldspathic norites and rhyolites in a strongly fractionated lunar crust. Proc. Lunar Sci. Conf. 1971, 2, 583-600.

101. Salpas, P.A.; Shervais, J.W.; Knapp, S.A.; Taylor, L.A. Petrogenesis of Lunar Granites: The Result of Apatite Fractionation (abstract). Lunar Planet. Sci. 1985, XVI, 726-727.

102. Seddio, S.M.; Korotev, R.L.; Jolliff, B.L.; Zeigler, R.A. Comparing the bulk composition of lunar granites, with Petrologic Implications. In Proceedings of the 41st Lunar and Planetary Science Conference, Woodlands, TX, USA, 1-5 March 2010; p. 2688.

103. Gullikson, A.L.; Hagerty, J.J.; Reid, M.R.; Rapp, J.F.; Draper, D.S. Silicic lunar volcanism: Testing the crustal melting model. Am. Mineral. 2016, 101, 2312-2321. [CrossRef]

104. Bonin, B. A-type granites and related rocks: Evolution of a concept, problems and prospects. Lithos 2007, 97, 1-29. [CrossRef]

105. Bonin, B. Extra-terrestrial igneous granites and related rocks: A review of their occurrence and petrogenesis. Lithos 2012, 153, 3-24. [CrossRef]

106. Glotch, T.D.; Lucey, P.G.; Bandfield, J.L.; Greenhagen, B.T.; Thomas, I.R.; Elphic, R.C.; Neil, B.; Wyatt, M.B.; Allen, C.C.; Donaldson Hanna, K.; et al. Highly Silicic Compositions on the Moon. Science 2010, 329, 1510-1513. [CrossRef] [PubMed]

107. Ridley, J. Ore Deposit Geology; Cambridge University Press: Cambridge, UK, 2013; 398p.

108. Lawrence, D.J.; Feldman, W.C.; Barraclough, B.L.; Elphic, R.C.; Maurice, S.; Binder, A.B.; Miller, M.C.; Prettyman, T.H. High resolution measurements of absolute thorium abundances on the lunar surface from the Lunar Prospector gamma-ray spectrometer. Geophys. Res. Lett. 2000, 26, 2681-2684. [CrossRef]

109. Zou, Y.; Xu, L.; Ouyang, Z. KREEP Rocks. Chin. J. Geochem. 2004, 23, 65-70.

110. Schrunk, D.; Sharp, B.; Cooper, B.; Thangavelu, M. The Moon: Resources, Future Development, and Settlement; Springer-Praxis: Chichester, UK, 2007. 
111. Chamberlain, P.G.; Taylor, L.A.; Podnieks, E.R.; Miller, R.J. A review of possible mining applications in space. In Resources of Near-Earth Space; Lewis, J.S., Matthews, M.S., Guerrieri, M.L., Eds.; University of Arizona Press: Tucson, AZ, USA, 1992; pp. 51-68.

112. Vanzani, V.; Marzari, F.; Dotto, E. Micrometeoroid Impacts on the Lunar Surface. In Proceedings of the 28th Lunar and Planetary Science Conference, Houston, TX, USA, 17-21 March 1997; p. 1095.

113. Mimoun, D.; Wieczorek, M.; Alkalai, L.; Banerdt, W.B.; Baratoux, D.; Bougeret, J.-L.; Bouley, S.; Cacconi, B.; Falcke, H.; Flohrer, J.; et al. Farside Explorer: Unique science from a mission to the farside of the Moon. Exp. Astron. 2012, 33, 529-585. [CrossRef]

114. Smith, A.; Crawford, I.A.; Gowen, R.A.; Ambrosi, R.; Anand, M.; Banerdt, B.; Bannister, S.M.; Bowles, N.; Braithwaite, C.; Brown, P.; et al. Lunar Net-A proposal in response to an ESA M3 call in 2010 for a medium sized mission. Exp. Astron. 2012, 33, 587-644. [CrossRef]

115. Newman, C.J. Seeking tranquility: Embedding sustainability in lunar exploration policy. Space Policy 2015, 33, 29-37. [CrossRef]

116. Du, X.; Graedel, T.E. Global In-Use Stocks of Rare Earth Elements: A First Estimate. Environ. Sci. Technol. 2011, 45, 4096-4101. [CrossRef] [PubMed]

(C) 2018 by the authors. Licensee MDPI, Basel, Switzerland. This article is an open access article distributed under the terms and conditions of the Creative Commons Attribution (CC BY) license (http:/ / creativecommons.org/licenses/by/4.0/). 